\title{
Remote sensing inversion and spatial variation of land surface temperature over mining areas of Jixi, Heilongjiang, China
}

\author{
Jia-shuo Cao ${ }^{1,2}$, Zheng-yu Deng ${ }^{1,2}$, Wen Li ${ }^{\text {Corresp., } 1}$, Yuan-dong Hu ${ }^{1,2}$ \\ ${ }^{1}$ College of Landscape Architecture, Northeast Forestry University, Harbin, Heilongjiang, China \\ 2 Key Laboratory for Garden Plant Germplasm Development \& Landscape Eco-Restoration in Cold Regions of Heilongjiang Province, Harbin, Heilongjiang, \\ China \\ Corresponding Author: Wen L \\ Email address: liwen@nefu.edu.cn
}

Background. Jixi is a typical mining city in China that has undergone dramatic changes in its land-use pattern of mining areas over the development of its coal resources. Impacts of coal mining activities have greatly affected the regional land surface temperature and ecological system.

Methods. The Landsat 8 Operational Land Imager (OLI) data from 2015 and 2019 were used from the Jiguan, Didao, and Chengzihe District of Jixi in Heilongjiang, China as the study area. The calculations to determine the land-use classification, vegetation coverage, and land surface temperature (LST) were performed using ArcGIS10.5 and ENVI 5.3 software packages. A correlation analysis revealed the impact of land-use type, vegetation coverage, and coal mining activities on LSTs.

Results. The results show significant spatial differentiation in the LSTs of Jixi City. The LSTs for various land-use types were ranked from high to low as follows: mining land > construction land > grassland > cultivated land $>$ forest land $>$ water area. The LST was lower in areas with high vegetation coverage than in other areas. For every 0.1 increase in vegetation coverage, the LST is expected to drop by approximately $0.75^{\circ} \mathrm{C}$. An analysis of mining land patches indicates that the patch area of mining lands has a significant positive correlation with both the average and maximum patch temperatures. The average patch temperature shows a logarithmic increase with the growth of the patch area, and within $200,000 \mathrm{~m}^{2}$, the average patch temperature increases significantly. The maximum patch temperature shows a linear increase with the patch area growth, and for every $100,000 \mathrm{~m}^{2}$ increase in the patch area of mining lands, the maximum patch temperature increases by approximately $0.81{ }^{\circ} \mathrm{C}$. The higher the average patch temperature of mining land, the higher the temperature in its buffer zone, and the greater its influence scope. This study provides a useful reference for exploring the warming effects caused by coal mining activities and the definition of its influence scope. 
1 Remote Sensing Inversion and Spatial Variation of

2 Land Surface Temperature over Mining Areas of Jixi,

3 Heilongjiang, China

4

5

6

7

\section{8}

Jia-shuo $\mathrm{Cao}^{1,2}$, Zheng-yu Deng ${ }^{1,2}$, Wen $\mathrm{Li}^{1}$, Yuan-dong $\mathrm{Hu}^{1,2}$

${ }^{1}$ College of Landscape Architecture, Northeast Forestry University, Harbin, Heilongjiang, China ${ }^{2}$ Key Laboratory for Garden Plant Germplasm Development \& Landscape Eco-Restoration in Cold Regions of Heilongjiang Province, Harbin, Heilongjiang, China

Corresponding Author:

Wen Li

Northeast Forestry University, 26 Hexing Road, Harbin, Heilongjiang, 150040, China Email address: liwen@nefu.edu.cn

\section{Abstract}

Background. Jixi is a typical mining city in China that has undergone dramatic changes in its land-use pattern of mining areas over the development of its coal resources. Impacts of coal mining activities have greatly affected the regional land surface temperature and ecological system.

Methods. The Landsat 8 Operational Land Imager (OLI) data from 2015 and 2019 were used from the Jiguan, Didao, and Chengzihe District of Jixi in Heilongjiang, China as the study area. The calculations to determine the land-use classification, vegetation coverage, and land surface temperature (LST) were performed using ArcGIS 10.5 and ENVI 5.3 software packages. A correlation analysis revealed the impact of land-use type, vegetation coverage, and coal mining activities on LSTs.

Results. The results show significant spatial differentiation in the LSTs of Jixi City. The LSTs for various land-use types were ranked from high to low as follows: mining land $>$ construction land $>$ grassland $>$ cultivated land $>$ forest land $>$ water area. The LST was lower in areas with high vegetation coverage than in other areas. For every 0.1 increase in vegetation coverage, the LST is expected to drop by approximately $0.75^{\circ} \mathrm{C}$. An analysis of mining land patches indicates that the patch area of mining lands has a significant positive correlation with both the average and maximum patch temperatures. The average patch temperature shows a logarithmic increase with the growth of the patch area, and within $200,000 \mathrm{~m}^{2}$, the average patch temperature increases significantly. The maximum patch temperature shows a linear increase with the patch area growth, and for every $100,000 \mathrm{~m}^{2}$ increase in the patch area of mining lands, the maximum patch temperature increases by approximately $0.81^{\circ} \mathrm{C}$. The higher the average patch temperature of mining land, the higher the temperature in its buffer zone, and the greater its influence scope. 


\section{Introduction}

43

44

45

46

47

48

49

50

51

52

53

54

55

56

57

58

59

60

61

62

63

64

65

66

67

68

69

70

71

72

73

74

This study provides a useful reference for exploring the warming effects caused by coal mining activities and the definition of its influence scope.

The land surface temperature (LST) comprehensively reflects the energy exchange between land and the atmosphere, which is an important geophysical parameter in the ground-air system ( $\mathrm{Li}$ et al., 2016; Zhu et al., 2016). Coupling the inversion results of LST with other parameters, such as land-use type and vegetation coverage, provides a scientific basis for ecological environmental protection (Li et al., 2014; Liang, \& Zhai, 2014; Xu, He \& Huang, 2013; Zhang et al., 2013). The commonly used LST inversion algorithms are divided primarily into the single-channel algorithm, multi-channel algorithm, and split-window algorithm (Zhu et al., 2016). Among them, the single-channel algorithms include the atmospheric correction method, Mono-window algorithm, and the Jiménez-Muñoz J.C single-channel algorithm (Qin, Karnieli \& Berliner, 2001; Jiménez-Muñoz et al., 2008). The multi-channel algorithms mainly include the day-night method, temperature emissivity separation algorithm, and graybody emissivity method (Gan et al., 2006; Gillespie, Rokugawa \& Matsunaga, 2002; Zhang et al., 2000). The split window algorithm is based mostly on data from the Landsat-TIRS, NOAA-AVHRR, and TERRA-MODIS (Rozenstein et al., 2014; Qin \& Karnieli, 2011; Mao et al., 2005).

Due to aggravation of the heat island effect, current research on LSTs is mostly focused on urban areas. Analyzing differences in LSTs for different land-use types optimizes the distribution of green space from the perspective of landscape patterning to reduce the heat island effect (Liu, 2016). However, mining areas, which are often affected by high temperatures and cause safety problems, have not attracted sufficient attention and are rarely studied.

Some research has shown that in the resource development process for resource-based cities, the land-use patterns in mining areas are constantly changing, which causes a series of impacts on the regional ecological environment (Li et al.,2018; Chabukdhara \& Singh, 2016; Xie et al., 2011). Therefore, research focusing on coupling between land-use patterns in mining areas and the ecological environment indicators, such as the LST, water environment quality, and biodiversity, has become vital to environmental sustainability (Zhou \& Wang, 2014; Xiao, Hu \& Fu, 2014; Hu, Duo \& Wang, 2018; Bian et al., 2018). Current research on land surface temperatures in mining areas mainly includes the temporal and spatial distribution characteristics of the surface temperature, the impact of ecological disturbance on the surface temperature, and others, where the scales are mostly at macro-regions (Li, Yang \& Lei, 2017; Qiu \& Hou, 2013; Xie et al., 2011;). This study specifically analyzes the overall and local distribution characteristics of LSTs from smaller scales to explore the radius of influence of high-temperature points. This provides a reference to establish heat alerts in mining areas. 
Jixi is a typical mining city in China that has undergone dramatic changes in its land-use pattern in the mining area during the development of coal resources. Significant amounts of cultivated land, forest land, and other land types have been replaced by industrial and mining sites, which has greatly affected the regional ecological environment. Impacts such as the atmospheric diffusion of pollutants and the rise of LSTs have affected the regional landscape and ecological systems (Pan et al., 2013; Liao, 2009). This paper uses data from the Landsat 8 OLI remote sensing images from 2015 and 2019 to determine LSTs using the radiation conduction equation over the study area, which encompasses the Jiguan, Didao, and Chengzihe District of Jixi. We analyzed the spatial differentiation and correlations of the LST with the land-use type and vegetation coverage to provide a theoretical framework to reduce the heat island effects caused by local urban development and coal mining activities.

\section{Materials \& Methods}

\section{Overview of the study area}

The study area encompasses the Jiguan, Didao, and Chengzihe District of Jixi, which are the main mining lands with a total area of $827.87 \mathrm{~km}^{2}$. Jixi is located in the southeast of Heilongjiang Province, between $130^{\circ} 24^{\prime} 24^{\prime \prime}-133^{\circ} 56^{\prime} 30^{\prime \prime}$ E, $44^{\circ} 51^{\prime} 12^{\prime \prime}-46^{\circ} 36^{\prime} 55^{\prime \prime}$ N. To the southeast and across the ocean in Russia, while to the west and south are Mudanjiang, and to the north is Qitaihe (Fig. 1). The province comprises Mishan, Hulin, and Jidong Counties and six other districts (Jiguan, Hengshan, Didao, Chengzihe, Lishu, and Mashan). The study area is part of the cold-temperate continental monsoon climate, where the average annual temperature is 3.7 ${ }^{\circ} \mathrm{C}$, the average precipitation is $537.5 \mathrm{~mm}$, the annual sunshine is $2709 \mathrm{~h}$ and the average frostfree period is $140 \mathrm{~d}$. The terrain is composed primarily of mountains, hills and plains.

Jixi is relatively rich in mineral resources with mutiple mining areas. However, there also are several abandoned mines that severely damage the ecological environment. In addition, urban construction and industrial development have encroached on grasslands, woodlands, and wetlands, which increases the ecological vulnerability and risks in these ecosystems (He, 2010).

\section{Data sources and preprocessing treatments}

This paper is based on the Landsat 8 OLI remote sensing images from 2015 and 2019, all of which are from the US Geological Survey (http://glovis.usgs.gov/). All images have a spatial resolution of $30 \mathrm{~m}$. The image strip numbers/rows used in this study are 115/28 and 115/29, respectively, and the imaging time was from July to September. Cloud cover in these images was less than $2 \%$, and they were interpreted and classified based on a series of preprocessing treatments, including radiation calibration, atmospheric correction, band synthesis and image cropping. 


\section{Analytical methods}

113 The spatial differentiation characteristics of the LST in the Jiguan, Didao, and Chengzihe

114 Districts of Jixi were used to identify heat islands and their influencing factors. We selected a

115 single-window algorithm for inversion of the LSTs. These results were used to analyze the

116 effects of the land-use type, vegetation coverage and coal mining activities on the spatial

117 distribution of LSTs.

118 Determining land-use classification and vegetation coverage

119 Land use is the most direct manifestation of the interaction between human activities and the

120

121

122

123

124

125

126

127

128

129

130

131

132

133

134

135

136

137

138

139

140

141

142

143

144

145

146

147

natural environment as it reflects this close relationship in both time and space (Mooney, Duraiappah \& Larigauderie, 2013; Liu et al., 2014). Typically, areas designated as land resources reflects the status of natural resources within the study area. Changes in land-use patterns inevitably cause changes in the LSTs and ecosystem functionality. Therefore, the study of land use is of great importance for regional ecological analyses (Marceau et al., 2003).

The relationship between vegetation coverage and the LST has become a focus of research on heat islands (Wang et al., 2011). Green vegetation affects LSTs through photosynthesis, transpiration and evapotranspiration. Ma et al. (2010) compared and analyzed five correlation degrees among planting parameters and LSTs, including the normalized difference vegetation index (NDVI), ratio vegetation index (RVI), greenness vegetation index (GVI), modified soil to adjust vegetation index (MSAVI) and vegetation coverage. They concluded that the correlation between vegetation coverage and the LST was both high and stable because it is not markedly influenced by spatial location or changes in the fraction or type of surface coverage. Therefore, the relationship between vegetation coverage and the LST was selected to study heat island effects within different land surfaces.

\section{Land-use classification}

The ENVI 5.3.1 (L3Harris Geospatial Solutions, Inc., Melbourne, FL, USA) and ArcGIS 10.5 (Esri, Corp., Redlands, CA, USA) were used to preprocess the original image data, which includes geometric correction, mosaic compilation, fusion, clipping, research scope extraction, image enhancement and supervised classification, before interpreting and analyzing the remote sensing imagery. The classification of land-use types in the study area was consistent with the standard land-use classification (GB/T 21010-2017). The study area was divided into six categories: forest lands, grasslands, construction lands, cultivated lands, mining lands and water areas. A maximum-likelihood approach was used for the classification. In the final stage of the study, the remote sensing image interpretation was validated by site surveys. The accuracy of the results was verified by establishing a confusion matrix. Random points were selected in the Erdas Imagine 2015 software for classification, where a certain number of random points were selected for each category. The classification of each random point was distinguished visually so

Peer) reviewing PDF | (2020:04:47707:2:1:NEW 2 Oct 2020) 
148 that the category to which each random point belongs is defined in the software. The user

149

150

151

152

153

154

155

156

157

158

159

160

161

162

163

164

165

166

167

168

169

170

171

172

173

174

175

176

\section{7}

178

179

180

181

182

accuracy, producer accuracy, and Kappa coefficient of the overall classification of each category were then calculated.

\section{Vegetation coverage calculation}

Plant coverage information is typically extracted from remote sensing images. Given the high accuracy of NDVI values estimated using remote sensing, it is one of the most widely used indexes ( $\mathrm{Mu}$ et al., 2012). A common method to calculate vegetation coverage is based on the hybrid pixel decomposition method, where it is assumed that each pixel of the remote sensing image is composed of soil and vegetation components. Thus, the information includes both a pure soil component and a pure vegetation component. In this case, we assumed that the NDVI value is a weighted average sum of the index values from both soil and vegetation information (Li, Fan, \& Wang, 2010), which is given as follows:

$$
N D V I=f_{v} \times N D V I_{v e g}+\left(1-f_{v}\right) \times N D V I_{\text {soil }},
$$

Where NDVI is the vegetation index value of mixed pixels; $\mathrm{NDVI}_{\mathrm{veg}}$ is the vegetation index of pure vegetation pixels; $\mathrm{NDVI}_{\text {soil }}$ is the vegetation index value of pure soil pixels; and $f_{\mathrm{v}}$ is the vegetation coverage. Thus, the formula for vegetation coverage $\left(f_{\mathrm{v}}\right)$ becomes:

$$
f_{v}=\left(N D V I-N D V I_{\text {soil }}\right) /\left(N D V I_{\text {veg }}-N D V I_{\text {soil }}\right) \text {, }
$$

In practice, the parameters can be selected in the following ways. (1) Take different NDVI $\mathrm{veg}_{\mathrm{v}}$ and $\mathrm{NDVI}_{\text {soil }}$ values for different soil and vegetation types. (2) Use the maximum and minimum NDVIs of the study area, $\mathrm{NDVI}_{\mathrm{veg}}=\mathrm{NDVI}_{\max }, \mathrm{NDVI}_{\text {soil }}=\mathrm{NDVI}_{\min }$. (3) Determine the NDVI value of the corresponding pixel based on measured data (Li et al., 2015). Under the influence of varying meteorological conditions, vegetation type and distribution, seasons, and other factors, both the $\mathrm{NDVI}_{\text {soil }}$ and $\mathrm{NDVI}_{\mathrm{veg}}$ values for different images vary to some extent.

The maximum and minimum values of the given confidence interval are selected, and the confidence value is determined primarily from the image size and clarity. As a comparison, the maximum NDVI images of 2015 and 2019 were extracted. In the NDVI frequency accumulation table, the NDVI with a frequency of 5\% was selected for NDVI $_{\text {soil }}$, and the NDVI with a frequency of $95 \%$ was selected for $\mathrm{NDVI}_{\mathrm{veg}}$. Finally, the vegetation coverage was obtained from Eq. (2).

\section{Land surface temperature inversion}

The LST inversion algorithms for single-infrared-band Landsat 8 OLI remote sensing data are based primary on the radioactive transfer equation (RTE), a universal single-channel algorithm, and a single-window algorithm (Ding \& Xu, 2008). Therefore, the RTE was selected to invert the LSTs in this study.

\section{Calculation of specific surface emissivity}


183 Remote sensing images were firstly classified into three types: water bodies, towns and natural

184

185

186

187

188

189

190

191

192

193

194

195

196

197

198

199

200

201

202

203

204

205

206

207

208

209

210

211

212

213

214

surfaces. The specific emissivity of water pixels is 0.995 , where other surface emissivity estimates were based on the following formulas (Chi, Zeng, \& Wang, 2016):

$$
\begin{aligned}
& \varepsilon_{\text {surface }}=0.9625+0.0614 f_{v}-0.0461 f_{v}^{2}, \\
& \varepsilon_{\text {building }}=0.9589+0.086 f_{v}-0.0671 f_{v}^{2},
\end{aligned}
$$

Where $\varepsilon_{\text {surface }}$ and $\varepsilon_{\text {building }}$ represent the specific emissivity of natural surface pixels and urban pixels, respectively.

\section{Radioactive transfer equation}

The RTE is also called the atmospheric correction method. It firstly estimates the impact of the atmosphere on the surface thermal radiation based on the information received by the satellite thermal infrared sensor. This is then subtracted from the total thermal radiation obtained by the sensor. The impact of the atmosphere on the surface can be used to obtain the intensity of surface thermal radiation. Assuming that the surface and the atmosphere have Lambertian properties for thermal radiation, the corresponding LST can be obtained as (You, \& Yan, 2009; Yue et al., 2019):

$$
L_{\lambda}=\left[\varepsilon \cdot B\left(T_{S}\right)+(1-\varepsilon) L_{\downarrow}\right] \cdot \tau+L_{\uparrow}
$$

Where $L_{\lambda}$ is the intensity of thermal radiation received by the satellite sensor, $\varepsilon(\mathrm{K})$ is the surface emissivity, $\mathrm{T}_{\mathrm{S}}$ is the true LST, $\mathrm{B}\left(\mathrm{T}_{\mathrm{S}}\right)\left(\mathrm{W} \mathrm{m}^{-2} \mathrm{sr}^{-1} \mu \mathrm{m}^{-1}\right)$ is the black body brightness corresponding to temperature $\mathrm{T}_{\mathrm{S}}$ derived from Planck's law, $\tau$ is the transmittance of the atmosphere at thermal infrared wavelengths, $\mathrm{L}_{\uparrow}\left(\mathrm{W} \mathrm{m}^{-2} \mathrm{sr}^{-1} \mu \mathrm{m}^{-1}\right)$ is the atmospheric upward radiance, and $\mathrm{L}_{\downarrow}\left(\mathrm{W} \mathrm{m}^{-2} \mathrm{sr}^{-1} \mu \mathrm{m}^{-1}\right)$ is the atmospheric downward radiance. Based on the $\mathrm{RTE}$, the $\mathrm{B}\left(\mathrm{T}_{\mathrm{S}}\right)$ can be obtained as (Wu et al., 2016; Hou, \& Zhang, 2019):

$$
B\left(T_{S}\right)=\left[L_{\lambda}-L_{\uparrow}-\tau \cdot(1-\varepsilon) L_{\downarrow}\right] / \tau \cdot \varepsilon
$$

Where $\tau, \mathrm{L}_{\uparrow}\left(\mathrm{W} \mathrm{m}^{-2} \mathrm{sr}^{-1} \mu \mathrm{m}^{-1}\right)$ and $\mathrm{L}_{\downarrow}\left(\mathrm{W} \mathrm{m}^{-2} \mathrm{sr}^{-1} \mu \mathrm{m}^{-1}\right)$ were determined from the official NASA website (http://atmcorr.gsfc.nasa.gov/) by inputting the imaging time, latitude and longitude, air pressure and other relevant information to the study area. After estimating the of black body radiance $\mathrm{B}\left(\mathrm{T}_{\mathrm{S}}\right)$, which is the same as the real temperature on the ground, the inverse function of Planck's law gives the real temperature on the ground as (Chen, 2014) :

$$
T_{S}=K_{2} / \ln \left(\frac{K_{1}}{B\left(T_{S}\right)}+1\right),
$$

Where $\mathrm{K}_{1}$ and $\mathrm{K}_{2}$ are constants obtained by querying the Landsat metadata file. In this case, $\mathrm{K}_{1}=774.8853$ and $\mathrm{K}_{2}=1321.0789$ for Landsat 8 TIRS band 10 .

\section{Normalized temperature index and temperature classification}


215 The ecological environment of coal mining areas is damaged to varying degrees, this changes

216 their LSTs and causes a series of significant ecological effects and environmental problems, such

217 as vegetation degradation and soil erosion (Dutta \& Agrawal, 2003; Zhou \& Zhang, 2005). We

218 used the urban heat island effect to explore the impact of coal mining activities on LSTs (Ye et

219 al., 2011; Li et al., 2019). The formula for the normalized temperature index is:

220

$$
T_{r}=\frac{\Delta T}{T_{\text {range }}}=\frac{T-T_{\min }}{T_{\max }-T_{\min }},
$$

221

222

223

224

225

226

227

228

229

230

231

232

233

234

235

236

237

238

239

240

241

242

243

244

245

246

247

Where $T_{r}$ is the normalized temperature index, $T$ is the temperature at any spatial position in the region, $\mathrm{T}_{\max }$ and $\mathrm{T}_{\min }$ are the highest and lowest temperature in the region, respectively.

The method of equal intervals is used to divide the temperature based on the site conditions and existing research (Sheng et al., 2010; Jia \& Liu, 2006). Once the maximum and minimum values of the inversion temperature are taken as endpoints, the temperature is divided into five equal-spaced intervals. These are a low-temperature zone, a low-middle-temperature zone, a middle-temperature zone, a middle-high-temperature zone, and a high-temperature zone. The normalized temperature indices for these levels were $0.0-0.2,0.2-0.4,0.4-0.6,0.6-0.8$, and $0.8-$ 1.0 , respectively (Table 1). Analyzing changes in the LST index at different distances from the mine allows evaluating the intensity and range of the heat island effect as caused by coal-mining activities.

\section{Analytical method of factors affecting land surface temperature}

The terrain over the study area is relatively flat, which facilitates farming, town construction, and coal mining activities. We analyzed the spatial differentiation of LSTs in this area, which was linked to land use, vegetation coverage and coal mining activities.

\section{The influence of land-use classification on land surface temperature}

The area and proportion of different types of land use were counted separately. Subsequently, the land-use and the LST maps were superimposed to obtain statistical data on the LSTs of various land-use types.

\section{The influence of vegetation coverage on land surface temperature}

A profile analysis more intuitively reflected the relationship between changes in LST and vegetation coverage at a given geographical location. Using the interpolation line function in ArcGIS 10.5 to view profile values of LST and vegetation coverage from 2015 and 2019 to compare and analyze their associated changes along profiles to evaluate the relationships between these variables.

\section{The influence of coal mining activities on land surface temperature}

\section{The influence of patch area}


248 Firstly, all mining areas within a distance of $1500 \mathrm{~m}$ from the edge of the study area were 249 screened. These selected mining area patches were then counted and grouped based on area. We 250 then combined these data with our LST inversion to determine the maximum, minimum, and 251 average LSTs for different patches. Finally, the influence of these mining land patches on the 252 LSTs were evaluated.

\section{The influence of buffer range}

254

255

256

257

258

259

260

261

262

263

264

265

266

267

268

269

270

271

272

273

274

275

276

277

278

279

280

281

282

283

284

Buffers with a range of 100-1500 m at intervals of $100 \mathrm{~m}$ were set for each of the patches. The average LST in each buffer zone was extracted, and the trends in the LSTs at varying distances from the mining area were analyzed.

\section{Results}

\section{Land surface temperature inversion}

The LST results for the Jiguan, Didao and Chengzihe Districts of Jixi in 2015 and 2019 are shown in Fig. 2 and Table 2. The temperatures in 2015 were in general higher than those in 2019. The average LST over the entire study area was $25.64^{\circ} \mathrm{C}$ in 2015 and $22.10^{\circ} \mathrm{C}$ in 2019 . There is a similarity in the spatial distribution patterns of their LSTs. High temperatures are concentrated in the south-central and southeast parts of the study area, while the temperatures in the west and north are relatively low. In these two years, the average LST in the Jiguan District was higher than averages in the other two districts, but its highest temperature was lower than the maximum recorded in the Didao and Chengzihe Districts. The highest temperatures over the entire study area were $42.29^{\circ} \mathrm{C}$, which was recorded at Shenghe Coal Mine in the Didao District. Likewise, the highest temperature in the Chengzihe District was recorded at Chengshan Coal Mine. Thus, mining areas had much higher LSTs than average. While only two years were selected for the analysis, similar results validate the conclusions.

The LSTs from 2015 and 2019 were normalized and divided into five levels, as shown in Fig. 3 and Table 3. The LSTs in the study area were assigned primarily to the low-temperature, lowmiddle-temperature, and middle-temperature zones, which covered the LST range of 19.16$33.04{ }^{\circ} \mathrm{C}$ in 2015 and $16.29-29.37^{\circ} \mathrm{C}$ in 2019 . Among them, the low-middle-temperature zone had the largest area as it accounted for more than $70 \%$ of the total study area. The hightemperature and middle-high-temperature zones had smaller areas. The high-temperature zone was distributed primarily within the Didao and Chengzihe Districts. The Shenghe Coal Mine accounted for $53.08 \%$ of the total area of the high-temperature zone in 2015 and rose to $59.04 \%$ in 2019. The proportion of the Chengshan Coal Mine in the total area of the high-temperature zone increased from $8.17 \%$ to $34.47 \%$ over these four years. Meanwhile, the low-temperature and low-middle-temperature zones were distributed mostly in the Didao and Chengzihe Districts, giving a large temperature difference between them. Therefore, local heat island effects were obvious within the study area. 


\section{Land-use classification}

287 Land-use types in the Jiguan, Didao, and Chengzihe Districts of Jixi in 2015 and 2019 are shown in Fig. 4 and Table 4. From 2015 to 2019, the area of forest land increased while the area of

289

290

291

292

293

294

295

296

297

298

299

300

301

302

303

304

305

306

307

308

309

310

311

312

313

314

315

316

317

318

319

cultivated land decreased. However, the dominant land-use types in the study area are still forest land and cultivated land. The forest land is distributed mostly in the northern part of the study area, while the cultivated land is distributed in the middle and southern parts. Construction land is concentrated in the Jiguan District, which increased significantly from $109.94 \mathrm{~km}^{2}$ to 133.69 $\mathrm{km}^{2}$ in the four considered years. The mining land is defined primarily by the Shenghe Coal Mine in the Didao District and the Chengshan Coal Mine in the Chengzihe District. The accuracy of the land-use classification was verified by establishing a confusion matrix. The matrix showed that the Kappa coefficients of the land-use maps in the interpreted periods are all above 0.8 , which meets the accuracy requirements for this study (Table 5).

\section{Vegetation coverage}

The remote sensing images of the study area were processed according to the mixed pixel decomposition method to obtain the vegetation coverage of the Jiguan, Didao, and Chengzihe District of Jixi (Fig. 5). The construction land in the eastern Jiguan District, Shenghe Coal Mine in the Didao District and Chengshan Coal Mine in the Chengzihe District had the lowest vegetation coverage. However, ongoing urbanization and coal mining activities have markedly affected vegetation coverage in many other areas as well.

\section{Correlation between land surface temperature and land-use types}

The main land types in the low-temperature and low-middle-temperature zone are water areas, forest land, grassland and cultivated land. The main land types in the high-temperature, middlehigh-temperature, and middle-temperature zones are construction land and mining land. There are large difference in the average LSTs among these land-use types (Table 6). The average LSTs for mining land, construction land and grassland were higher than the average LST for the study area. Among them, mining land had the highest average LSTs $\left(33.33^{\circ} \mathrm{C}\right.$ in 2015 and 29.63 ${ }^{\circ} \mathrm{C}$ in 2019), yielding temperature anomalies of $7.69^{\circ} \mathrm{Cin} 2015$ and $7.53^{\circ} \mathrm{C}$ in 2019 . The water area had the lowest average LSTs $\left(21.72{ }^{\circ} \mathrm{C}\right.$ in 2015 and $19.31^{\circ} \mathrm{C}$ in 2019). At the same time, the temperature standard deviation within the mining land was also relatively large, with a difference of $18.02^{\circ} \mathrm{C}$ between the minimum and maximum temperatures.

\section{Correlation between land surface temperature and vegetation coverage}


320

321

322

323

324

325

326

327

328

329

330

331

332

333

334

335

336

337

338

339

340

341

342

343

344

345

346

347

348

349

350

351

352

353

354

355

An east-west transect was drawn across the study are, and the data from 2019 were used to analyze changes in the LSTs with vegetation coverage. Every 25 pixel points on the profile were assigned to a group, and the average value of the vegetation coverage and LST in each group was calculated to obtain 56 data sets. Finally, a linear fit was performed between the vegetation coverage and average LST, and the coefficient of determination was assessed (Fig. 6). Areas with low vegetation coverage were associated with higher LSTs. In addition, as vegetation coverage decreased, the LSTs increased. The trends in LST and vegetation coverage were opposite with reciprocal change patterns.

The linear fit of the average LST and vegetation coverage (Fig. 7) shows that if the vegetation coverage increases by 0.1 , the average LST is expected to decrease by approximately $0.75^{\circ} \mathrm{C}$. This constitutes a strong negative relationship between the LST and vegetation coverage. Using the SPSS 24 (IBM, Corp., Armonk, NY, USA) indicated a correlation coefficient of R $=-0.780$. This indicates a significant correlation at the 0.01 confidence level (both sides). Thus, green vegetation has a significant cooling effect on the land surface.

\section{Correlation between land surface temperature and coal mining activities}

This study mainly considers spatial variations when exploring the correlation between the LST and mining activities. Therefore, the data of the most recent year (2019) is selected for the analysis, and the spatial distribution of the LST is analyzed based on the patch area and buffer sizes.

\section{Correlation between land surface temperature and patch area of mining lands}

The mining areas were grouped based on patch area after screening them within $1500 \mathrm{~m}$ of the edge of the study area. The maximum, minimum and average LSTs of each patch were calculated from the 52 data sets (Table 7). Correlations among the average patch area and the average and maximum patch temperatures were analyzed using SPSS 24. Our analysis indicates that the patch was strongly positively correlated with the average and maximum patch temperatures.

Correlation between the patch area and average patch temperature (Fig. 8) yielded $\mathrm{R}=0.571$. This indicates a significant correlation at the 0.01 confidence level (both sides). The determination coefficient of the fit logarithmic function was $\mathrm{R}^{2}=0.487$, indicating that larger patch sizes promote a greater average patch temperature. Within $200,000 \mathrm{~m}^{2}$, the average patch temperature increases rapidly with the size of the patch area. Once above $200,000 \mathrm{~m}^{2}$, the average patch temperature increases more slowly.

The correlation between the patch area and maximum patch temperature (Fig. 9) yielded $\mathrm{R}=$ 0.645 . This indicates a significant correlation at the 0.01 confidence level (both sides). The determination coefficient of the linear fit was $\mathrm{R}^{2}=0.415$, indicating that larger patch sizes 
356 promote a greater maximum patch temperature. If the patch area of mining land increases by

$357100,000 \mathrm{~m}^{2}$, the maximum patch temperature will increase by approximately $0.81^{\circ} \mathrm{C}$.

358 Correlation between land surface temperature and various buffer sizes

359 The schematic diagram of buffer zone in mining land patch is shown in Fig 10. A correlation

360

361

362

363

364

365

366

367

368

369

370

371

372

373

374

375

376

377

378

379

380

381

382

383

384

385

386

387

388

389

390

analysis was performed on average patch area, average patch temperature, maximum patch temperature of mining land and the average LST in buffer zones at 100-1500 m reviewed at $100 \mathrm{~m}$ intervals (Table 8 ). The temperature of the buffer zones within $0-100 \mathrm{~m}$ was strongly correlated with the patch area, average patch temperature, and maximum patch temperature of the mining land. In the 100-200 m buffer zone, the correlation between the temperature and the average area was not significant. Therefore, a higher correlation was found for the entire buffer zone with the average and maximum patch temperatures, while a lower correlation was found with the patch area. Thus, the correlation between the temperature in the buffer zone and the average patch temperature was most relevant.

To further study the correspondence between the average patch temperature of mining land and the temperature in the buffer zones, the 52 data sets were sorted based on their average patch temperatures from smallest to largest. Each of the 13 groups was then compiled into a new group. The average number and the average temperature of the corresponding buffer zone in each new group were calculated to obtain four new data sets (Table 9).

Figure 11 shows that the further the buffer zone was from the mine land patch, the lower its temperature. In 0-200 $\mathrm{m}$ buffer zones, the average temperature changed drastically, while the average temperature outside the $200 \mathrm{~m}$ zone varied little. The range of this heating effect is approximately $700 \mathrm{~m}$ in Group 1, $1200 \mathrm{~m}$ in Group 2 and 3, and more than $1400 \mathrm{~m}$ in Group 4. Therefore, a larger average patch temperature in the mining land causes a higher temperature in its buffer zone, and the greater the scope of its influence.

\section{Discussion}

\section{Impact of coal mining activities on surface temperatures}

As the largest coal city in Heilongjiang Province, Jixi has always utilized coal as its leading industry. The main types of coal mining wasteland in Jixi City include mining subsidence, land occupation, polluted wasteland, and excavated land, which account for $0.48 \%, 82.0 \%, 6.82 \%$, and $10.71 \%$ of the total coal mining wasteland, respectively (Di, Guan \& Zheng, 2015). Coal mining activities generate a significant amount of heat. Thus, regional heating within the city has intensified when coupled with their high-energy consumption and high-heat producing enterprises (Hu, Zhao \& Dong, 2010). The ongoing economic development of mining areas has increased both the population density and heat production from urban infrastructure. 
391

392

393

394

395

396

397

398

399

400

401

402

403

404

405

406

407

408

409

410

411

412

413

414

415

416

417

418

419

420

421

422

423

424

425

426

427

The correlation between LST and coal mining activities has resulted in larger mining lands with higher average and maximum patch temperatures. The available literature has shown that the size, shape, number, and boundary properties of these patches affect their energy transmissions. According to landscape ecological theory, the size and shape of these patches also affect their energy accumulation. Likewise, some researchers have recognized that larger patches of construction land have higher degrees of aggregation, more regular shapes, higher LSTs, and more significant heat island effects (Yu, 2006; Fu, 2001; Xie, Wang \& Fu, 2011; Xu et al., 2015). Some studies have analyzed different types of disturbances at the interior of mining lands, among which dumps, opencast coal pits, and industrial centers have higher contributions to local warming (Xie et al., 2011; Liu J, 2016). Exposed coal and coal gangue easily absorb heat and cause increased temperatures, while piled coal gangue hills are prone to heat and spontaneous combustion (Hao, 2011). Therefore, many factors cause high temperatures in mining land.

Quantitative research on the impact of mining land indicates a strong warming effect within a buffer zone of 0-200 $\mathrm{m}$ around mining land patches. As the distance from the mining land increases, the warming effects gradually weakens. Mining land patches with higher average patch temperatures have larger temperature-affected buffer zones. Changes in the local meteorological conditions, such as temperature rise, affect local species, which impacts the ecological conditions of the entire region. However, the strength of the warming effect and the size of its influence range are not only related to the distance from the mining land patch but may also be related to the average temperature of the entire area during the analysis (Liao, 2009). This specific correlation requires further study.

To date, regulations on the ecological and environmental protection are aimed only at the ecological and environmental indicators within the mining area, which cannot achieve regional ecological protection. Although it seems intuitive that coal production enterprises or units engaged in corresponding activities have taken the responsibility of protecting the ecology and environment, this does not cover the entire affected area of coal mining production activities. To protect the ecological quality of the area while developing coal resources, the scope of environmental protection in mining areas should be defined more scientifically and rationally.

\section{Impact of different land-use types on surface temperature}

Our results show that land-use types have a dominating impact on the LST. The LSTs of the Jiguan, Didao, and Chengzihe District of Jixi were primarily within the range of $16.29-42.29{ }^{\circ} \mathrm{C}$ in the two considered years. The low-middle-temperature zone had the largest area, which accounted for $70.53 \%$ and $72.21 \%$ of the total area. The low-temperature zone was distributed primarily over water areas, forest lands and cultivated lands. The high-temperature zone was distributed mostly over the construction land and mining land, especially the Shenghe Coal Mine in the Didao District and the Chengshan Coal Mine in the Chengzihe District. 
428

429

430

431

432

433

434

435

436

437

438

439

440

441

442

443

444

445

446

447

448

449

450

451

452

453

454

455

456

457

458

459

460

461

462

463

464

465

The temperatures in 2019 were generally lower than those in 2015. From a normalized comparison, it is seen that the high-temperature and low-temperature zones increased in 2019. Along with the clustered development of mining land patches, the land surface temperature shows a polarizing trend. The expansion of some high-temperature zones may be due to the continued development of coal mines. The increased low-temperature areas may be due to the reclamation and restoration of vegetation in mining areas. Based on governmental planning ("Mineral Resources Planning of Jixi City (2016-2020)" and "Special Planning for Reclamation and Utilization of Desert Land of Industrial Mining Area and Mining Subsidence Area in Jixi City (2014-2020)") from 2015 to 2019, the coal industry wastelands in Chengzihe and Didao Districts were treated to a certain extent, and the reclaimed land was converted into cultivated land, forest land, and construction land. These lands will be used for agricultural production, creating recreational landscapes, and improving the ecological environment.

In recent years, the development of coal resources in Jixi has been rapid. Additionally, the spatial distribution of mines has also changed (Yang, 2013). Construction and mining activities have reduced the "cooling" land-use types, such as forest and cultivated lands (Wang et al., 2020), and replaced them with "warming" types, like construction and mining lands. The available literature has shown that urban expansion is the main driving process of land cover changes and consequently rise of LST (Pal \& Ziaul, 2017), which is consistent with our findings. With changes in land-use types, natural vegetation has been replaced by impervious concrete and construction land, which has caused significant changes like heat radiation from the underlying city surface (Wang et al., 2013). These man-made surfaces have a strong light absorptive effect and can quickly raise the local LST (Hien et al., 2011). In addition, building facades can reflect light multiple times, heating the near-surface atmosphere and cause LSTs to rise significantly (Miao et al., 2009). Some studies have also shown that the heating effect of construction lands, especially compact low-rise buildings, is very obvious (Das, Das \& Mandal, 2020). Among the six considered land-use types, the LSTs of water area, forest land, and cultivated land were lower than the average LST for the study area. Water-permeable areas of the study region, such as water areas and forest land, ensure efficient heat exchange between the soil and the atmosphere. Water can evaporate, which absorbs heat in the environment and has an overall cooling effect (Zhang et al., 2013). Therefore, not only by balancing the land-use types, but also by optimizing appropriate urban planning, the increase in LST can be adjusted to reduce the impact of urbanization on the ecological environment (Das \& Das, 2020).

\section{Impact of vegetation coverage on land surface temperatures}

Our coupling analysis showed that changes in vegetation coverage are very important factors that affecting ecological status change. There is a significant negative correlation between LST and vegetation coverage, which has also been confirmed by other works (Estoque, Murayama \& Myint, 2017; Jiang, Zeng \& Zeng, 2015; Duan \& Zhang, 2012; Wu, Xu \& Tan, 2007; Yue, Xu \& 
$466 \mathrm{Xu}, 2006)$. As vegetation blocks sunlight, it reduces the amount of solar radiation that reaches 467 the surface, while plant transpiration also reduces the LST (Cui, Li \& Ji, 2018). In areas with 468 high vegetation coverage, the LST was lower than in other areas, illustrating the degree to which 469 vegetation could effectively alleviate heat island effect.

470 Therefore, municipal bodies should carefully consider the balance between ecological 471 protection and economic development. The focus should be on vegetation restoration and 472 environmental governance in areas where heat emissions are concentrated, such as abandoned 473 mine sites and barren areas. Meanwhile, increasing the proportion of green space, improving the 474 diversity and complexity of the landscape, and dividing the impervious surface with vegetation 475 when developing urban construction land and coal mines can significantly reduce the LST and 476 alleviate heat island effects.

477

\section{Conclusions}

479 Our findings show that coal mining activities and urban expansion are the primary factors 480 affecting LSTs. These two factors change land-use types and vegetation coverage, which results 481 in an abnormal heat flux. There were large differences in the LSTs among the various land-use 482 types in Jixi City. The LSTs for the considered land-use types were ranked from high to low, as 483 follows: mining land $>$ construction land $>$ grassland $>$ cultivated land $>$ forest land $>$ water area. 484 The average LST difference between the mining land and water area was more than $10{ }^{\circ} \mathrm{C}$ each 485 year.

486 Correlations between LST and vegetation coverage indicate that they have a significant

487

488

489

490

491

492

493

494

495

496

497

498

499

500

501 negative relationship. The LST was lower in areas with higher vegetation coverage than in other areas. For every 0.1 increase in vegetation coverage, the surface temperature is expected to drop by approximately $0.75^{\circ} \mathrm{C}$, indicating the extent to which vegetation can effectively alleviate warming effects.

The correlation between the LST and coal mining activities indicates the patch area of the mining land has a significant positive correlation with both the average and maximum patch temperatures. The average patch temperature shows a logarithmic increase with the growth of the patch area; thus, the average patch temperature increases significantly within $200,000 \mathrm{~m}^{2}$. The maximum patch temperature shows a linear increase with the growth of the patch area; thus, the maximum patch temperature increases by approximately $0.81^{\circ} \mathrm{C}$ for every $100,000 \mathrm{~m}^{2}$ increase in the patch area of mining land. A higher correlation was found between the average patch temperature and the temperature in the buffer zone. This study found that the higher the average patch temperature of mining land, the higher the temperature in its buffer zone, and the greater the scope of its influence. As the distance from the mining land increased, its heating effect weakened. 
502 Full consideration should be given to vegetation restoration in mining areas to reduce the 503 warming effect from coal mining activities, especially in abandoned mining land, by increasing 504 the total vegetation coverage in the study area. The existing large coal mine land patches need to 505 be divided by plants or water areas. Thus, the scope of environmental protection in mining areas 506 needs to be correctly defined. Meanwhile, in future urban layouts, downtown areas should 507 maintain a proper distance from coal mining land. This study provides a useful reference to 508 explore the warming effects caused by coal mining activities and the definition of its influence 509 scope.

510

\section{Funding}

512 This work was supported by the Fundamental Research Funds for the Central Universities

513 (No.2572017CA12, No.2572018CP06).

514

515

516

References

517

518

Bian ZF, Lei SG, Jin D, Wang L. 2018. Several basic scientific issues related to mined land

519

520

521

522

523

524

525

526

527

528

529

530

531

532

533

534

535

536

537 remediation. Journal of China Coal Society 43(01): 190-197

DOI 10.13225/j.cnki.jccs.2017.4004

Chabukdhara M, Singh OP. 2016. Coal mining in northeast India: an overview of environmental issues and treatment approaches. International Journal of Coal Science \& Technology 3(2):87-96 DOI 10.1007/s40789-016-0126-1

Chen Y. 2014. A preliminary study on the urban heat island effect based on Landsat 8: case of Xiamen City. Geomatics \& Spatial Information Technology 37(02):123-128 DOI 10.3969/j.issn.1672-5867.2014.02.036

Chi TL, Zeng J, Wang ST. 2016. Research of the relationship between vegetation fraction and evolution of thermal environment in Zhengzhou based on RS and GIS technology. Chinese Landscape Architecture 32(10):78-83

Cui LL, Li GS, Ji DJ. 2018. Heat island effect and its relationship with land use in Chengdu City. Chinese Journal of Ecology 37(05):1518-1526

DOI 10.13292/j.1000-4890.201805.001

Das M, Das A. 2020. Assessing the relationship between local climatic zones (LCZs) and land surface temperature (LST) - A case study of Sriniketan-Santiniketan Planning Area (SSPA), West Bengal, India. Urban Climate 32:100591 DOI 10.1016/j.uclim.2020.100591

Das M, Das A, Mandal S. 2020. Outdoor thermal comfort in different settings of a tropical planning region: A study on Sriniketan-Santiniketan Planning Area (SSPA), Eastern India. Sustainable Cities and Society 63:102433 DOI 10.1016/j.scs.2020.102433 
538 Ding F, Xu HQ. 2008. Comparison of three algorithms for retrieving land surface temperature

539

540

541

542

543

544

545

546

547

548

549

550

551

552

553

554

555

556

557

558

559

560

561

562

563

564

565

566

567

568

569

570

571

572

573

574

575

576

577 from Landsat TM thermal infrared band. Journal of Fujian Normal University (Natural Science Edition) 99(01):91-96

Duan JL, Zhang XL. 2012. Correlative analysls of the diversity patterns of regional surface water, NDVI and thermal environment. Chinese Journal of Applied Ecology 23(10):28122820 DOI $10.13287 / j .1001-9332.2012 .0400$

Dutta RK, Agrawal M. 2003. Restoration of opencast coal mine spoil by planting exotic tree species: a case study in dry tropical region. Ecological Engineering 21(2-3):143-151 DOI 10.1016/j.ecoleng.2003.10.002

Estoque RC, Murayama Y, Myint SW. 2017. Effects of landscape composition and pattern on land surface temperature: An urban heat island study in the megacities of Southeast Asia. Science of the Total Environment 577:349-359 DOI 10.1016/j.scitotenv.2016.10.195

Fu BJ. 2001. Principle and response of landscape ecology. Beijing: Science Press.

He L. 2010. Synthetic evaluation of ecological environment influenee, ecological environmental protection and ecology repair countermeasures for open-pit mining. D. Thesis, Northwest University.

Hou YC, Zhang DY. 2019. Comparison study on land surface temperature retrieval algorithms based on Landsat 8 remote sensing image 35(10):142-147

DOI 10.11924/j.issn.1000-6850.casb18120100

Hien WN, Kardinal JS, Samsudin R, Eliza A, Ignatius M. 2011. A climatic responsive urban planning model for high density city: Singapore's commercial district. International Journal of Sustainable Building Technology and Urban Development 2(4):323-330

Hu WL, Zhao P, Dong ZY. 2010. Thermal environment effect of coal mining area and its ecological significance based on TM data. Journal of Hefei University of Technology (Natural Science) 33(05):741-744

Hu ZQ, Duo LH, Wang XT. 2018. Principle and method of reclaiming subsidence land with inter-layers of filling materals. Journal of China Coal Society 43(01):198-206 DOI 10.13225/j.cnki.jccs.2017.4003

Jia HF, Liu XH. 2006. Principle and application of environmental remote sensing. Beijing: Tsinghua University Press.

Jiang MZ, Zeng SP, Zeng J. 2015. Urban expansion of Tianjin and the micro climate characteristics evolution: based on the urban thermal environment perspective. Journal of Arid Land Resources and Environment 29(09):159-164 DOI 10.13448/j.cnki.jalre.2015.310

Li DK, Fan JZ, Wang J. 2010. Change characteristics and their causes of fractional vegetation coverage (FVC) in Shanxi Province. Chinese Journal of Applied Ecology 21(11):2896-2903 DOI 10.13287/j.1001-9332.2010.0404

Li HZ, Chen JS, Han Y, Zhang YN. 2019. Micro-scale research of the impact factors on urban thermal environment: a case study of Luohu District, Shenzhen. Ecology and Environmental Sciences 28(08):1622-1631 
578

579

580

581

582

583

584

585

586

587

588

589

590

591

592

593

594

595

596

597

598

599

600

601

602

603

604

605

606

607

608

609

610

611

612

613

614

615

616

617

DOI 10.16258/j.cnki.1674-5906.2019.08.015

Li RL, Shi YJ, Yao YM, Tian FP, Hu Y. 2014. Temporal and spatial variation of oasis cold island effect in Ganzhou district of Zhangye based on Landsat TM/ETM +. Journal of Arid Land Resources and Environment 28(09):139-144 DOI 10.13448/j.cnki.jalre.2014.09.012

Li ZL, Duan SB, Tang BH, Wu H, Ren HZ, Yan GJ, Tang RL, Leng P. 2016. Review of methods for land surface temperature derived from thermal infrared remotely sensed data. Journal of Remote Sensing 20(05):899-920 DOI 10.11834/jrs.20166192

Liang BP, Zhai LX. 2014. A Research on spatial-temporal changes and correlation between vegetation fraction and land surface temperature in Guilin during 1991-2006. Chinese Landscape Architecture 30(07):77-81

Liao CH. 2009. Study on ecological effects of mining landscape and ecological restoration in Yangquan coal mining region. M. Thesis, Tsinghua University.

Liu JY, Kuang WH, Zhang ZX, Xu XL, Qin YW, Ning J, Zhou WC, Zhang SW, Li RD, Yan CZ, Wu SX, Shi XZ, Jiang N, Yu DS, Pan XZ, Chi WF. 2014. Spatiotemporal characteristics, patterns and causes of land use changes in China since the late 1980s. Acta Geographica Sinica 69(01):3-14 DOI 10.11821/dlxb201401001

Ma W, Zhao ZM, Liu X, Yan DC. 2010. A quantitative analysis of the relationship between vegetation indices and land surface temperature based on remote sensing: a case study of TM data for Beijing. Remote Sensing for Land \& Resources 22(04):108-112 DOI 10.6046/gtzyyg.2010.04.22

Marceau DJ, Howarth PJ, Dubois JM, Gratton DJ. 2003. Evaluation of the grey-level cooccurrence matrix method for land-cover classification using spot imagery. IEEE Transactions on Geoscience and Remote Sensing 28(4):513-519

DOI 10.1109/TGRS.1990.572937

Miao S, Chen F, Lemone MA, Tewari M, Wang Y. 2009. An observational and modeling study of characteristics of urban heat island and boundary layer structures in Beijing. Journal of Applied Meteorology and Climatology 48(3):484-501 DOI 10.1175/2008JAMC1909.1

Mooney HA, Duraiappah A, Larigauderie A. 2013. Evolution of natural and social science interactions in global change research programs. Proceedings of the National Academy of Sciences 110:3665-3672 DOI 10.1073/pnas.1107484110

Mu SJ, Li JL, Chen YZ, Gang CC, Zhou W, Ju WM. 2012. Spatial differences of variations of vegetation coverage in inner Mongolia during 2001-2010. Acta Geographica Sinica 67(09):1255-1268 DOI 10.11821/xb201209010

Pal S, Ziaul S. 2017. Detection of land use and land cover change and land surface temperature in English Bazar urban centre. The Egyptian Journal of Remote Sensing and Space Science 20(1):125-145 DOI 10.1016/j.ejrs.2016.11.003

Pan DL, Huang ZQ, Zhang DR, Wang J, Zhou LF. 2013. Mapping land subsidence related to underground coal fires in the Wuda Coalfield (Northern China) using a small stack of ALOS PALSAR differential interferograms. Remote Sensing 5(3): 1152-1176 
618

619

620

621

622

623

624

625

626

627

628

629

630

631

632

633

634

635

636

637

638

639

640

641

642

643

644

645

646

647

648

649

650

651

652

653

654

655

656

DOI 10.3390/rs5031152

Wang RC, Hou H, Murayama Y, Derdouri A. 2020. Spatiotemporal Analysis of Land Use/Cover Patterns and Their Relationship with Land Surface Temperature in Nanjing, China. Remote Sensing 12(3):440 DOI 10.3390/rs12030440

Wang W, Shen SH, Zhao XY, Yang SB. 2011. Comparative analysis on quantitative relationships between NDVI, RSR and land surface temperature. Resources and Environment in the Yangtze Basin 20(04):439-444

Wu JW, Xu JH, Tan WQ. 2007. Study on the relationship of urban heat island and vegetation abundance in Shanghai City. Remote Sensing Technology and Application 22(01):26-30 DOI 10.11873/j.issn.1004-0323.2007.1.26

Wu ZG, Jiang T, Fan YL, Chen LJ. 2016. Land surface temperature retrieval and result analysis based on Landsat 8 data in Wuhan City. Chinese Journal of Engineering Geophysics 13(01):135-142 DOI 10.3969/j.issn.1672-7940.2016.01.023

Xiao W, Hu ZQ, Fu YH. 2014. Zoning of land reclamation in coal mining area and new progresses for the past 10 years. International Journal of Coal Science \& Technology 1(2):177-183 DOI 10.1007/s40789-014-0024-3

Xie MM, Wang YL, Fu MC. 2011. An overview and perspective about causative factors of surface urban heat island effects. Progress in Geography 30(01):35-41 DOI 10.11820/dlkxjz.2011.01.004

Xu S, Li FX, Zhang LB, Zhou, L. 2015. Spatiotemporal changes of thermal environment landscape pattern in Changsha. Acta Ecologica Sinica 35(11):3743-3754 DOI 10.5846/stxb201310142477

Xu HQ, He H, Huang SL. 2013. Analysis of fractional vegetation cover change and its impact on thermal environment in the Hetian basinal area of County Changting, Fujian Province, China. Acta Ecologica Sinica 33(10):2954-2963 DOI 10.5846/stxb201205150720

Yang JH. 2013. Evaluation Research on Land Sustainable Use of Jixi City with Coal Resourceexhausted. M. Thesis, Northeast Agricultural University.

Ye CH, Liu YH, Liu WD, Liu C, Quan WJ. 2011. Research on urban surface heat environment monitoring indexes and its application. Meteorological Science and Technology 39(01):95-101 DOI 10.19517/j.1671-6345.2011.01.019

You X, Yan LM. 2009. Retrieving land surface temperature from the ETM+ image radioactive transfer equation. Sci-Tech Information Development \& Economy 19(27):134-136+138

Yu XX. 2006. Landscape Ecology. Beijing: Higher Education Press.

Yue TC, Nie S, Pan H, Li LC. 2019. Land surface temperature retrieval and urban heat island effect based on Landsat 8 image in Fuzhou City. Journal of Northwest Forestry University 34(05):154-160 DOI 10.3969/j.issn.1001-7461.2019.05.24

Yue WZ, Xu JH, Xu LH. 2006. An analysis on eco-environmental effect of urban land use based on remote sensing images: a case study of urban thermal environment and NDVI. Acta Ecologica Sinica 26(05):1450-1460 
657 Zhang F, Tashpolat T, Ding JL, Mamat S, Nigala T, Gui DW, Wang JS. 2013. The heat

658

659

660

661

662

663

664

665

666

667

668

669

670

671

672

673 environment of land surface of typical oasis in upper reaches of Tarim river with remote sensing images. Journal of Arid Land Resources and Environment 27(04):111-116

DOI 10.13448/j.cnki.jalre.2013.04.014

Zhang H, Qi ZF, Ye XY, Cai YB, Ma WC, Chen MN. 2013. Analysis of land use/land cover change, population shift, and their effects on spatiotemporal patterns of urban heat islands in metropolitan Shanghai, China. Applied Geography 44:121-133

DOI 10.1016/i.apqeoq.2013.07.021

Zhou JH, Wang LJ. 2014. Comprehensive study on ecological restoration and land exploitation of mining subsidence in suburbs of Chinese mining cities. International Journal of Coal Science \& Technology 1(2):248-252 DOI:10.1007/s40789-014-0035-0

Zhou QX, Zhang QR. 2005. Environmental problems and ecological countermeasures of coalmining areas in the old industrial base, Northeastern China. Chinese Journal of Ecology 24(03):287-290 DOI 10.13292/j.1000-4890.2005.0254

Zhu ZR, Cheng PG, Gui X, Teng Y, Tong CZ. 2016. Overview of surface temperature inversion algorithm. Geomatics \& Spatial Information Technology 39(05):70-75

DOI 10.3969/j.issn.1672-5867.2016.05.020 


\section{Table $\mathbf{1}$ (on next page)}

Table 1 The relationship between the normalized temperature index values and assigned temperature grades 
1

2

\begin{tabular}{cc}
\hline Normalized temperature index & Temperature grade \\
\hline $0.0-0.2$ & Low temperature zone \\
$0.2-0.4$ & Low-middle temperature zone \\
$0.4-0.6$ & Middle temperature zone \\
$0.6-0.8$ & Middle-high temperature zone \\
$0.8-1.0$ & High temperature zone \\
\hline
\end{tabular}

Table 1 The relationship between the normalized temperature index values and assigned temperature grades

3

4 


\section{Table 2 (on next page)}

Table 2 Statistics on LST for the study area in 2015 and 2019 


\begin{tabular}{|c|c|c|c|c|c|c|c|c|}
\hline \multirow{3}{*}{ Range } & \multicolumn{8}{|c|}{ Land surface temperature $/{ }^{\circ} \mathrm{C}$} \\
\hline & \multicolumn{4}{|c|}{2015} & \multicolumn{4}{|c|}{2019} \\
\hline & MEAN & MIN & MAX & STD & MEAN & MIN & MAX & STD \\
\hline Jiguan District & 27.16 & 21.58 & 38.97 & 2.52 & 23.24 & 17.42 & 33.64 & 2.23 \\
\hline Didao District & 25.23 & 19.16 & 42.29 & 1.92 & 21.75 & 17.18 & 38.08 & 1.63 \\
\hline Chengzihe District & 25.53 & 19.45 & 39.13 & 2.48 & 22.34 & 16.29 & 35.26 & 2.14 \\
\hline Total & 25.64 & 19.16 & 42.29 & 2.28 & 22.10 & 16.29 & 38.08 & 1.95 \\
\hline
\end{tabular}


Table 3 (on next page)

Table 3 LST normalization results for the study area in 2015 and 2019 


\begin{tabular}{|c|c|c|c|c|c|}
\hline \multirow{2}{*}{ Temperature grade } & \multirow{2}{*}{$\begin{array}{l}\text { Normalized } \\
\text { temperature } \\
\text { index }\end{array}$} & \multicolumn{2}{|c|}{2015} & \multicolumn{2}{|c|}{2019} \\
\hline & & $\mathbf{L S T} /{ }^{\circ} \mathrm{C}$ & Percentage & $\mathbf{L S T} /{ }^{\circ} \mathrm{C}$ & Percentage \\
\hline Low & & & & & \\
\hline temperature zone & $0.0-0.2$ & $19.16-23.78$ & $18.19 \%$ & $16.29-20.65$ & $19.31 \%$ \\
\hline $\begin{array}{l}\text { Low-middle } \\
\text { temperature zone }\end{array}$ & $0.2-0.4$ & $23.78-28.41$ & $70.53 \%$ & $20.65-25.01$ & $72.21 \%$ \\
\hline $\begin{array}{l}\text { Middle } \\
\text { temperature zone }\end{array}$ & $0.4-0.6$ & 28.41-33.04 & $10.34 \%$ & $25.01-29.37$ & $7.79 \%$ \\
\hline $\begin{array}{l}\text { Middle-high } \\
\text { temperature zone }\end{array}$ & $0.6-0.8$ & $33.04-37.66$ & $0.90 \%$ & $29.37-33.72$ & $0.66 \%$ \\
\hline $\begin{array}{c}\text { High } \\
\text { temperature zone }\end{array}$ & $0.8-1.0$ & $37.66-42.29$ & $0.04 \%$ & $33.72-38.08$ & $0.03 \%$ \\
\hline Total & $0.0-1.0$ & $19.16-42.29$ & $100.00 \%$ & $16.29-38.08$ & $100.00 \%$ \\
\hline
\end{tabular}

2 
Table 4 (on next page)

Table 4 Land-use structure for the study area in 2015 and 2019 


\begin{tabular}{ccccc}
\hline \multirow{2}{*}{ Land-use } & \multicolumn{2}{c}{$\mathbf{2 0 1 5}$} & \multicolumn{2}{c}{$\mathbf{2 0 1 9}$} \\
\cline { 2 - 4 } & Area / km $\mathbf{~}^{2}$ & Percentage / \% & Area / km ${ }^{2}$ & Percentage / \% \\
\hline Forest land & 294.07 & $35.52 \%$ & 304.18 & $36.74 \%$ \\
Grassland & 52.95 & $6.39 \%$ & 80.4 & $9.71 \%$ \\
Construction land & 109.94 & $13.28 \%$ & 133.69 & $16.15 \%$ \\
Cultivated land & 357.39 & $43.17 \%$ & 295.07 & $35.64 \%$ \\
Mining land & 7.10 & $0.86 \%$ & 6.76 & $0.82 \%$ \\
Water area & 6.42 & $0.78 \%$ & 7.77 & $0.94 \%$ \\
Total & 827.87 & $100.00 \%$ & 827.87 & $100.00 \%$ \\
\hline
\end{tabular}

2 


\section{Table 5 (on next page)}

Table 5 Accuracy evaluation of land use classification for the study area in 2015 and 2019 
2015

\begin{tabular}{|c|c|c|c|c|c|c|c|}
\hline Land-use & $\begin{array}{c}\text { Forest } \\
\text { land }\end{array}$ & Grassland & $\begin{array}{c}\text { Construction } \\
\text { land }\end{array}$ & $\begin{array}{c}\text { Cultivated } \\
\text { land }\end{array}$ & $\begin{array}{c}\text { Mining } \\
\text { land }\end{array}$ & $\begin{array}{c}\text { Water } \\
\text { area }\end{array}$ & Total \\
\hline Forest land & 1646 & 2 & - & - & - & - & 1648 \\
\hline Grassland & - & 150 & - & - & - & - & 150 \\
\hline Construction land & 3 & - & 2406 & - & - & - & 2409 \\
\hline Cultivated land & - & 4 & 2 & 1737 & - & - & 1743 \\
\hline Mining land & - & - & 17 & - & 346 & - & 363 \\
\hline Water area & - & - & - & - & - & 319 & 319 \\
\hline Total & 1649 & 156 & 2425 & 1737 & 346 & 319 & 6632 \\
\hline Producers Accuracy & 99.82 & 96.15 & 99.22 & 1000 & 100 & 98.46 & - \\
\hline Users Accuracy & 99.88 & 100 & 99.67 & 99.66 & 95.32 & 100 & - \\
\hline
\end{tabular}

2019

\begin{tabular}{|c|c|c|c|c|c|c|c|}
\hline Land-use & $\begin{array}{c}\text { Forest } \\
\text { land }\end{array}$ & Grassland & $\begin{array}{c}\text { Construction } \\
\text { land }\end{array}$ & $\begin{array}{c}\text { Cultivated } \\
\text { land }\end{array}$ & $\begin{array}{c}\text { Mining } \\
\text { land }\end{array}$ & $\begin{array}{c}\text { Water } \\
\text { area }\end{array}$ & Total \\
\hline Forest land & 858 & 35 & - & - & - & - & 893 \\
\hline Grassland & - & 37 & 34 & 10 & 1 & - & 82 \\
\hline Construction land & - & - & 1710 & 35 & 18 & - & 1763 \\
\hline Cultivated land & 2 & 11 & 19 & 821 & 2 & - & 855 \\
\hline Mining land & - & - & 2 & - & 263 & - & 265 \\
\hline Water area & - & - & - & - & - & 231 & 231 \\
\hline
\end{tabular}




\begin{tabular}{cccccccc}
\hline Total & 860 & 83 & 1765 & 866 & 284 & 231 & 4089 \\
Producers Accuracy & 99.77 & 44.58 & 96.88 & 94.8 & 92.61 & 92.4 & - \\
Users Accuracy & 96.08 & 45.12 & 96.07 & 95.8 & 99.25 & 100 & - \\
\hline
\end{tabular}

2 Note: In 2015, Overall Classification Accuracy $=99.50 \%$; Overall Kappa Statistics $=0.9932$;

4 
Table 6(on next page)

Table 6 Statistics on LST of different land-use types in 2015 and 2019 


\begin{tabular}{|c|c|c|c|c|c|c|c|c|}
\hline \multirow{3}{*}{ Land use types } & \multicolumn{8}{|c|}{ Land surface temperature $/{ }^{\circ} \mathrm{C}$} \\
\hline & \multicolumn{4}{|c|}{2015} & \multicolumn{4}{|c|}{2019} \\
\hline & MEAN & MIN & MAX & STD & MEAN & MIN & MAX & STD \\
\hline Forest land & 23.95 & 20.79 & 30.89 & 1.01 & 21.07 & 17.38 & 26.41 & 0.97 \\
\hline Grassland & 26.55 & 21.94 & 36.27 & 1.45 & 23.21 & 18.77 & 30.56 & 1.43 \\
\hline Construction land & 29.12 & 20.59 & 41.74 & 2.26 & 24.62 & 17.24 & 35.04 & 1.96 \\
\hline Cultivated land & 25.74 & 21.35 & 33.71 & 1.20 & 21.73 & 18.26 & 29.14 & 1.09 \\
\hline Mining land & 33.33 & 24.27 & 42.29 & 2.50 & 29.63 & 20.35 & 38.08 & 2.31 \\
\hline Water area & 21.72 & 19.16 & 29.12 & 2.30 & 19.31 & 16.29 & 27.56 & 1.74 \\
\hline
\end{tabular}

2 
Table 7 (on next page)

Table 7 Statistics on LST and patch area for mining lands 


\begin{tabular}{|c|c|c|c|c|c|c|c|c|}
\hline \multirow{2}{*}{$\begin{array}{l}\text { Average area } \\
\qquad / \mathbf{m}^{2}\end{array}$} & \multicolumn{2}{|c|}{ LST $/{ }^{\circ} \mathrm{C}$} & \multirow{2}{*}{$\begin{array}{c}\text { Average area } \\
\qquad / \mathbf{m}^{2}\end{array}$} & \multicolumn{2}{|c|}{ LST $/{ }^{\circ} \mathrm{C}$} & \multirow{2}{*}{$\begin{array}{c}\text { Average area } \\
\qquad / \mathbf{m}^{2}\end{array}$} & \multicolumn{2}{|c|}{ LST $/{ }^{\circ} \mathrm{C}$} \\
\hline & MEAN & MAX & & MEAN & MAX & & MEAN & MAX \\
\hline 900 & 26.88 & 30.98 & 18000 & 29.09 & 30.27 & 53100 & 30.22 & 31.95 \\
\hline 1800 & 27.38 & 32.30 & 19800 & 29.17 & 35.11 & 58500 & 27.85 & 29.48 \\
\hline 2700 & 27.25 & 30.87 & 20700 & 31.85 & 33.43 & 61200 & 29.79 & 31.73 \\
\hline 3600 & 26.50 & 30.49 & 21600 & 29.60 & 30.61 & 65700 & 31.90 & 34.51 \\
\hline 4500 & 27.97 & 31.39 & 23400 & 29.29 & 30.25 & 82800 & 30.79 & 32.06 \\
\hline 5400 & 28.23 & 30.16 & 24300 & 28.47 & 31.40 & 88200 & 29.63 & 31.78 \\
\hline 6300 & 27.46 & 31.61 & 25200 & 29.02 & 30.51 & 110700 & 28.62 & 30.18 \\
\hline 7200 & 27.26 & 30.87 & 26100 & 27.89 & 29.30 & 114300 & 31.36 & 33.22 \\
\hline 8100 & 26.52 & 29.54 & 27000 & 28.26 & 29.43 & 135000 & 28.94 & 31.05 \\
\hline 9000 & 27.57 & 29.63 & 28800 & 28.59 & 31.25 & 139500 & 28.70 & 31.22 \\
\hline 9900 & 28.39 & 30.63 & 31500 & 27.54 & 30.19 & 162000 & 29.85 & 32.49 \\
\hline 10800 & 28.23 & 31.98 & 32400 & 28.33 & 31.92 & 175500 & 30.14 & 32.31 \\
\hline 12600 & 28.26 & 33.02 & 36000 & 28.48 & 30.26 & 179100 & 30.13 & 32.35 \\
\hline 13500 & 29.44 & 30.58 & 39600 & 28.54 & 30.53 & 241200 & 29.04 & 31.41 \\
\hline 14400 & 26.99 & 29.11 & 40500 & 27.86 & 30.36 & 490500 & 31.15 & 33.10 \\
\hline 15300 & 25.58 & 26.63 & 43200 & 28.33 & 30.66 & 626400 & 31.58 & 35.26 \\
\hline 16200 & 27.53 & 28.46 & 48600 & 29.85 & 31.84 & 754200 & 31.58 & 38.08 \\
\hline 17100 & 26.57 & 29.39 & & & & & & \\
\hline
\end{tabular}


Table 8(on next page)

Table 8 Correlation between LST and buffer zone within the mining lands 


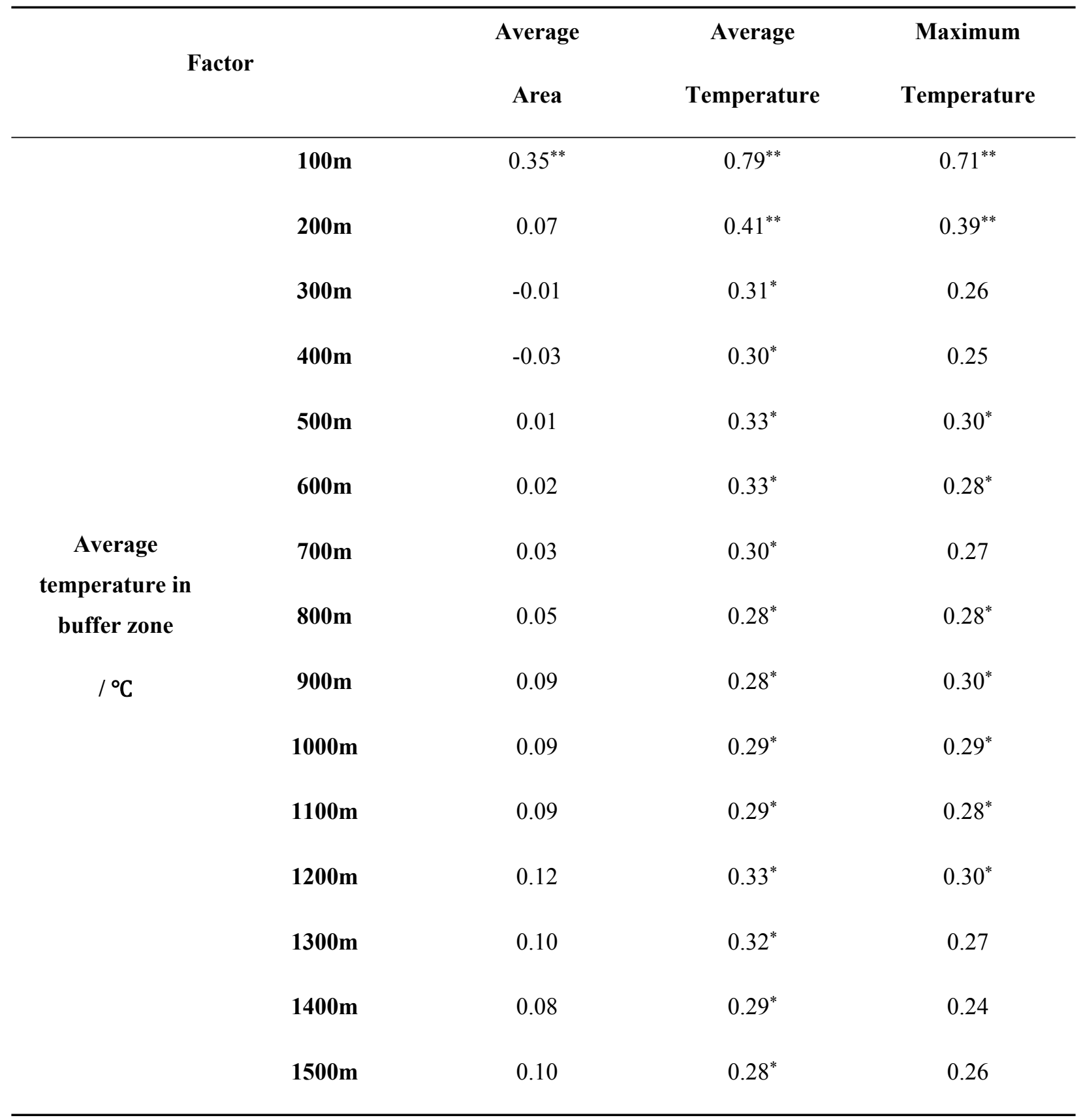

2 Note: $*$ means $\mathrm{p}<0.05, * *$ means $\mathrm{p}<0.01$ 
Table 9 (on next page)

Table 9 Correspondence between LST and buffer zone within the mining lands 


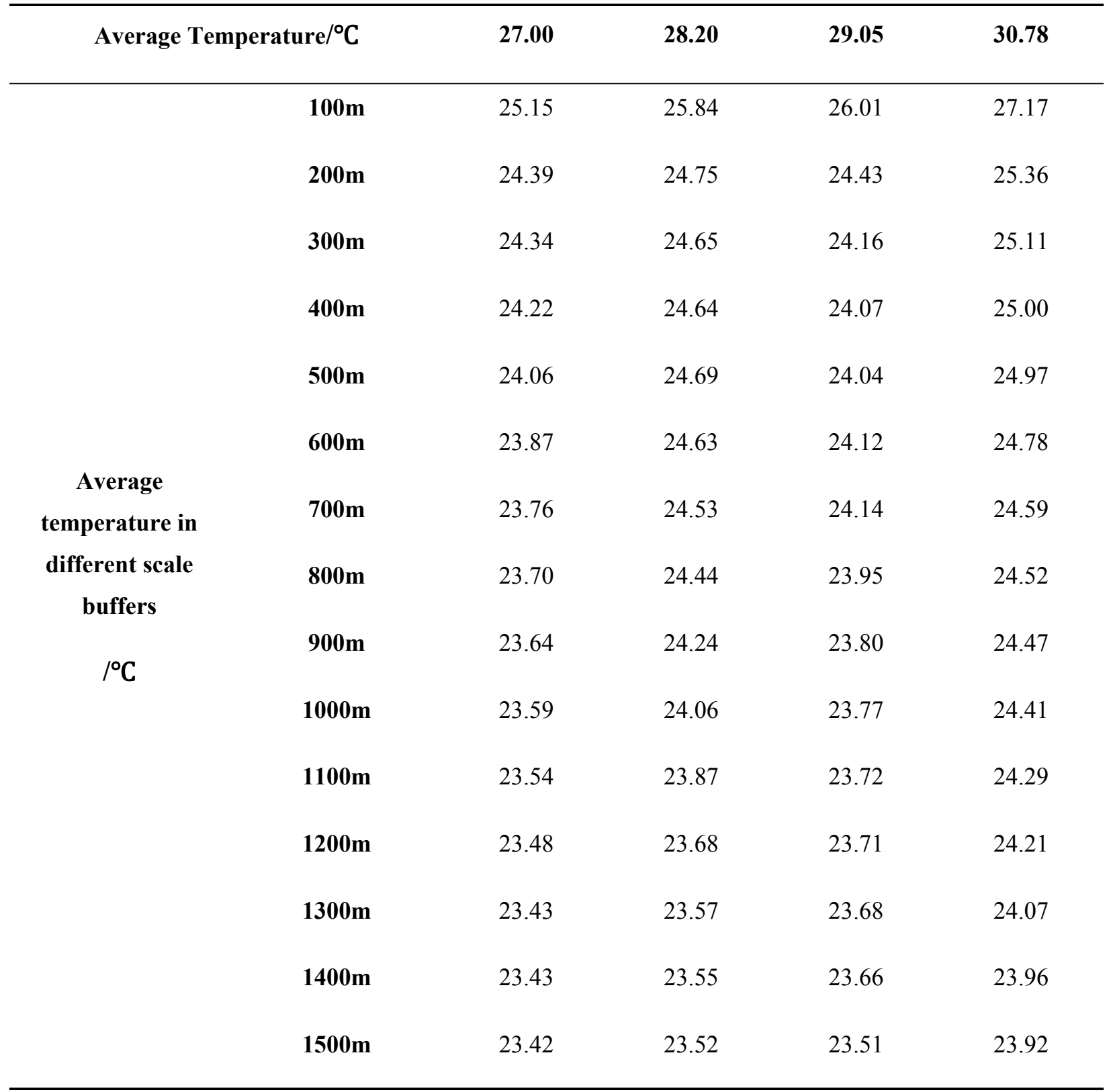


Figure 1

Figure 1 Location map showing the three districts of Jixi comprising the study area

Map representing the geostrategic importance of the study area: (A) Jixi City, Heilongjiang Province, China, (B) Three districts of Jixi.

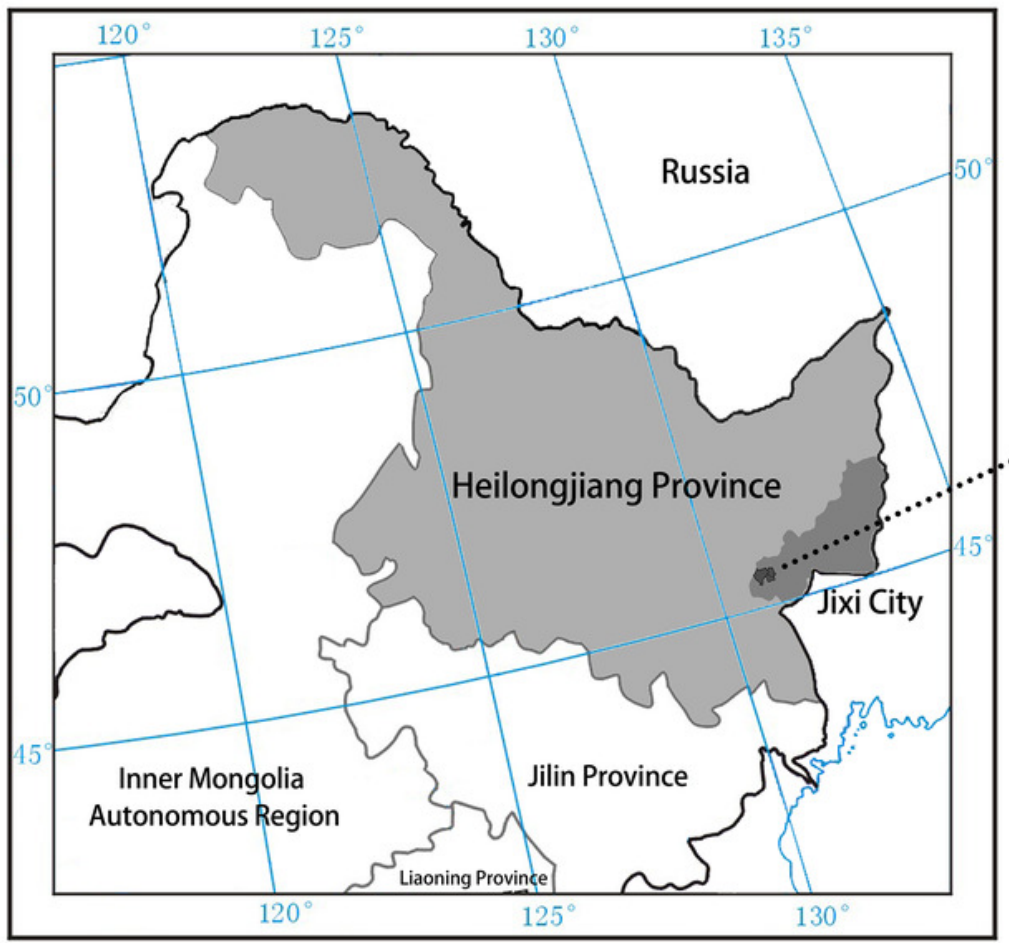

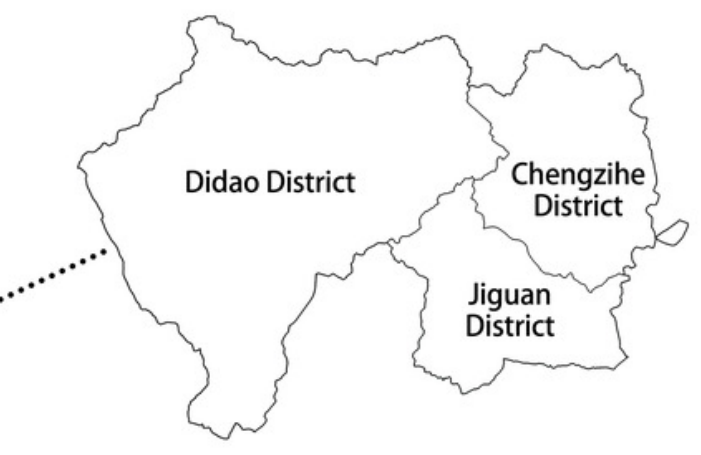

(B) Study Area

(A)

Three districts of Jixi, Heilongjiang Province, China 


\section{Figure 2}

Land surface temperature $\left({ }^{\circ} \mathrm{C}\right)$ results for the three districts of Jixi in 2019

Land surface temperature (LST) maps for (A) 2015, (B) 2019 of the three districts in Jixi, Heilongjiang, China.

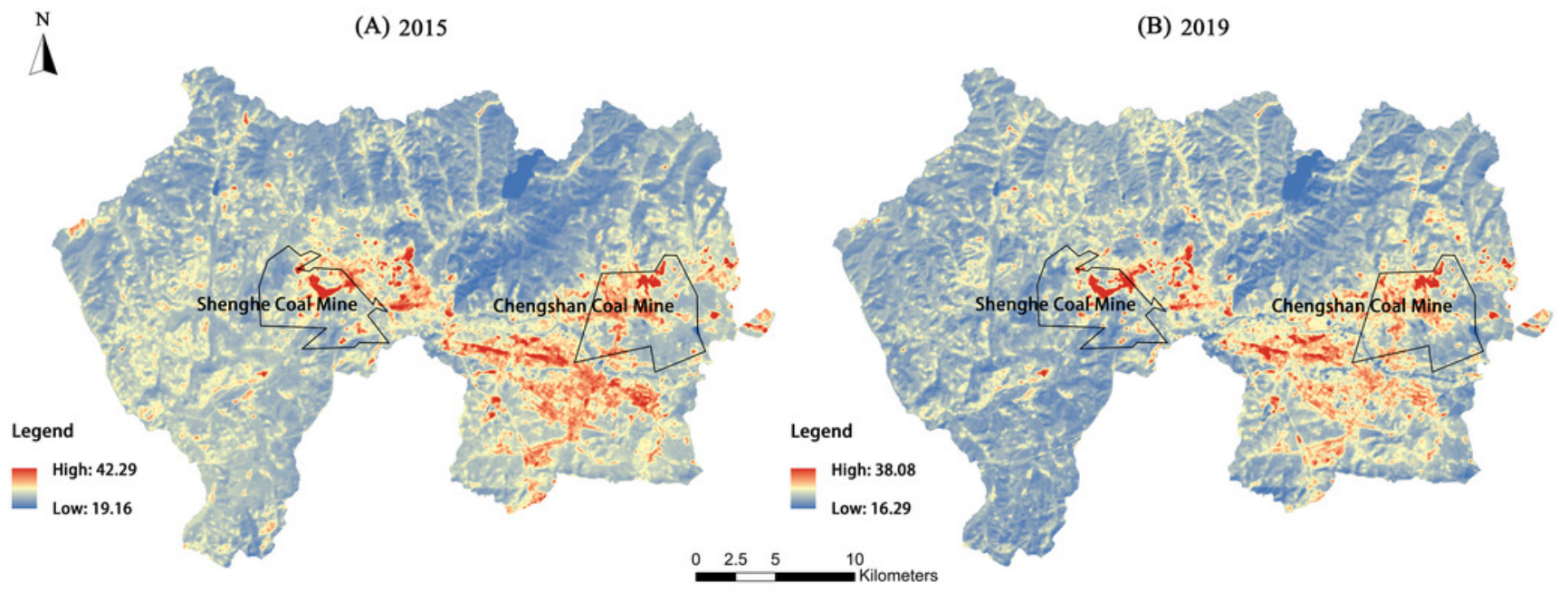


Figure 3

Figure 3 Spatial distribution of land surface temperature levels of the study area in 2015 and 2019

Spatial distribution of land surface temperature levels for (A) 2015, (B) 2019 of the three districts in Jixi, Heilongjiang, China.

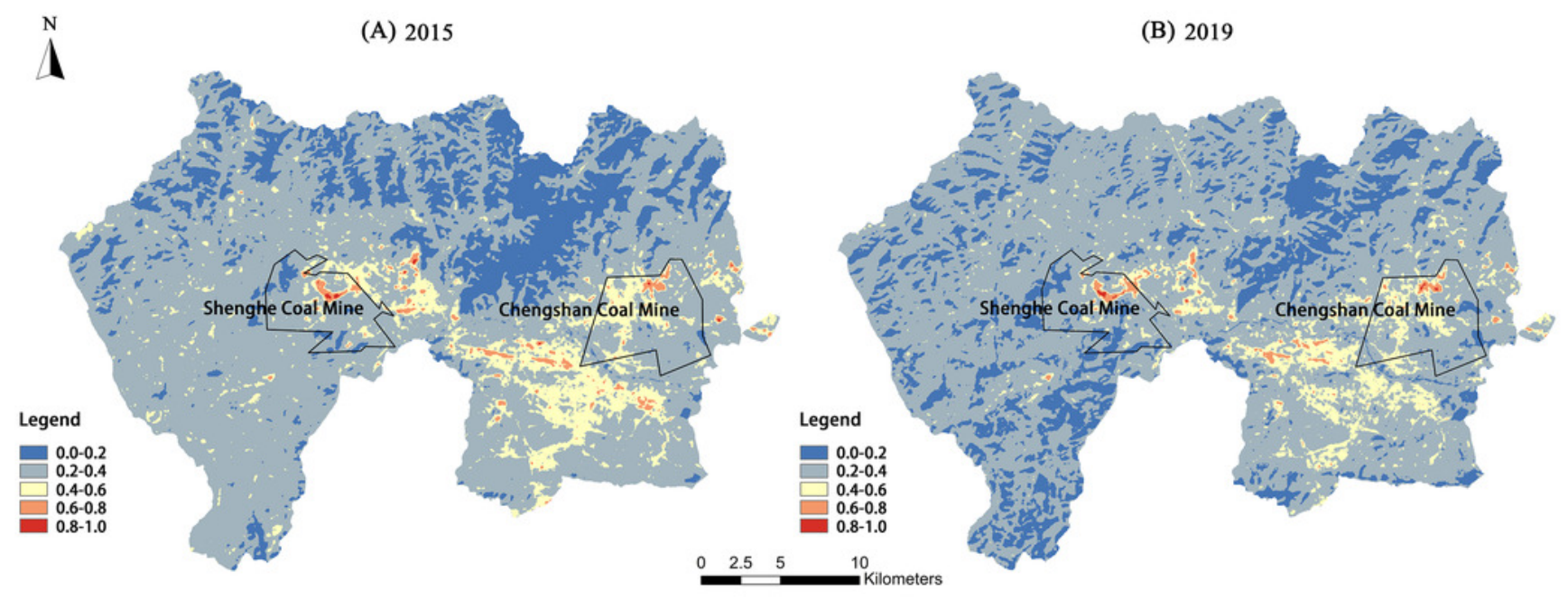


Figure 4

Figure 4 Land-use types of the study area in 2015 and 2019

Land-use types for (A) 2015, (B) 2019 of the three districts in Jixi, Heilongjiang, China.

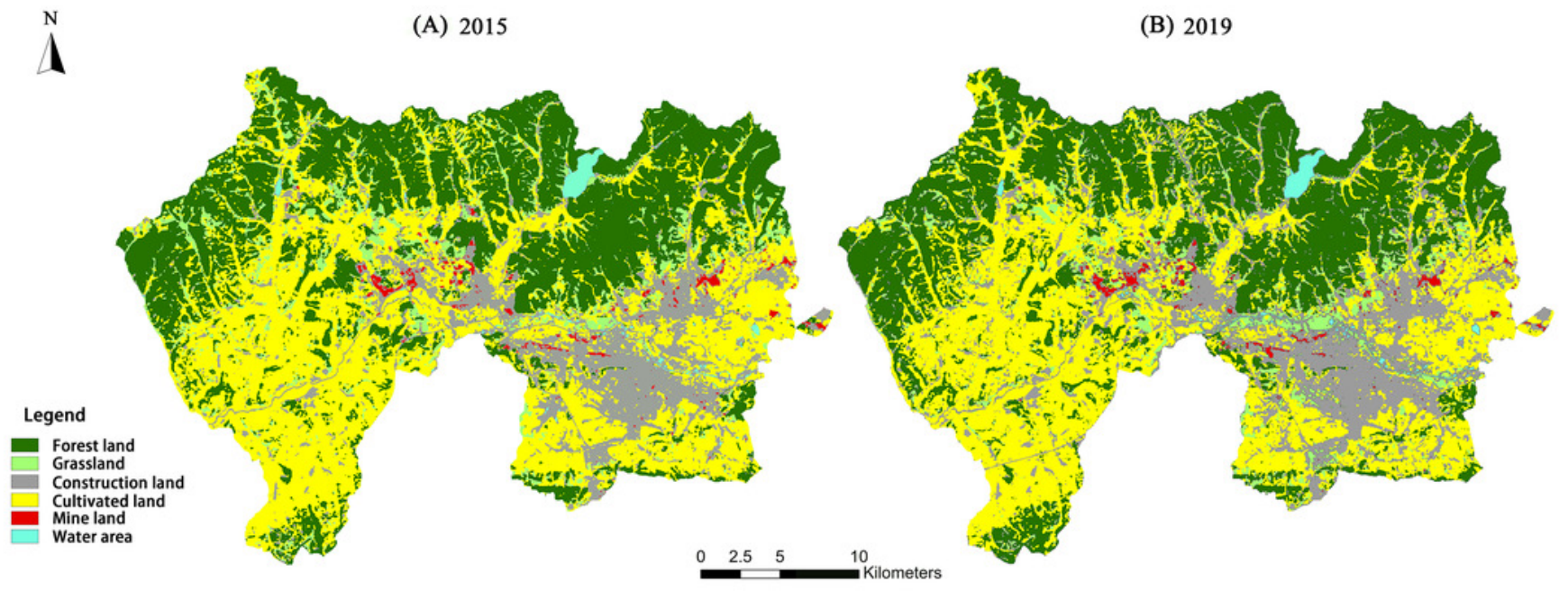


Figure 5

Figure 5 Vegetation coverage of the study area in 2015 and 2019

Vegetation coverage for (A) 2015, (B) 2019 of the three districts in Jixi, Heilongjiang, China.

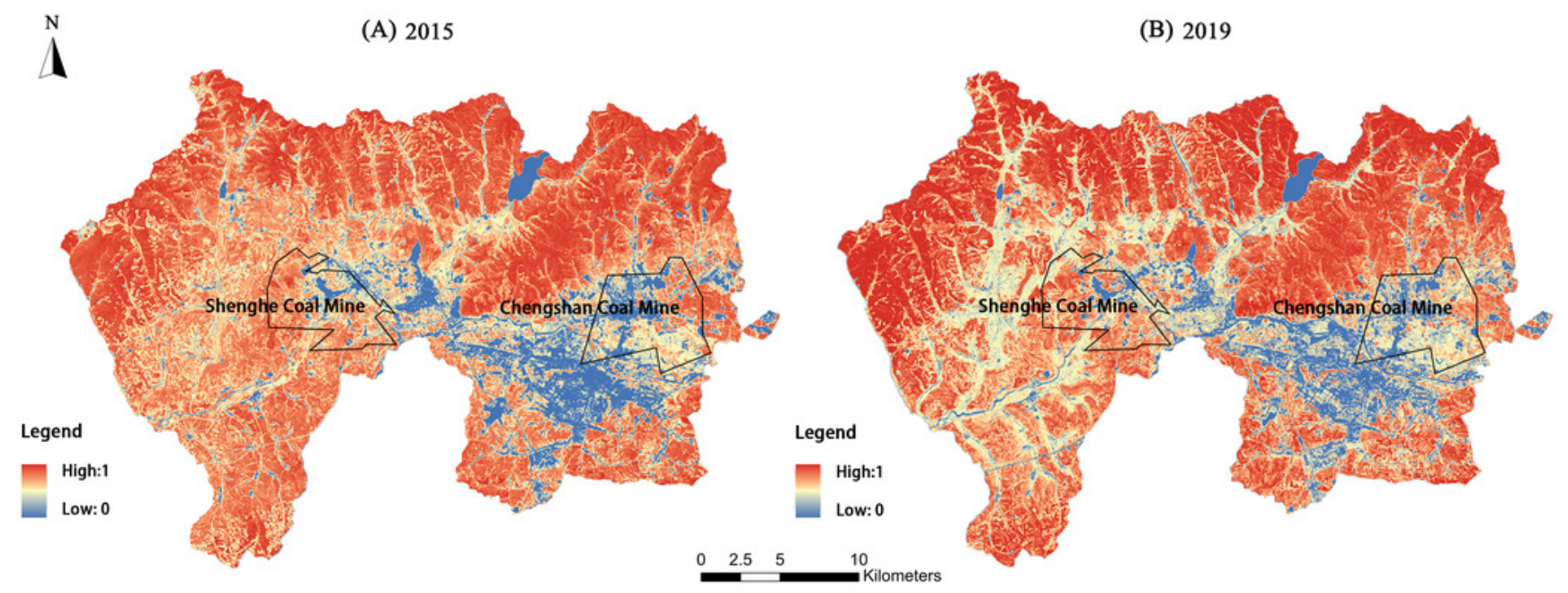


Figure 6

Figure 6 Variation in land surface temperature (LST) and vegetation coverage in pixel groups (1-56) along an E-W profile

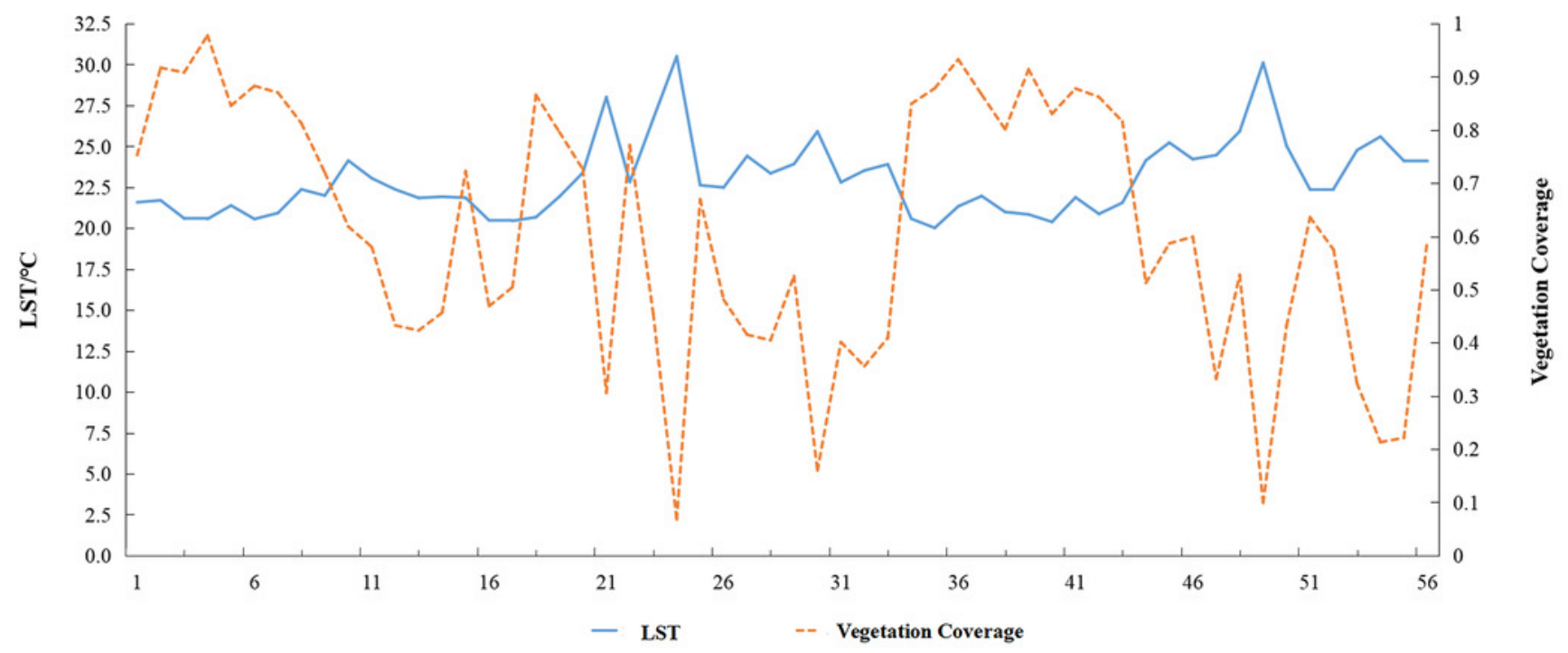


Figure 7

Figure 7 Correlation between land surface temperature (LST) and vegetation coverage of the study area

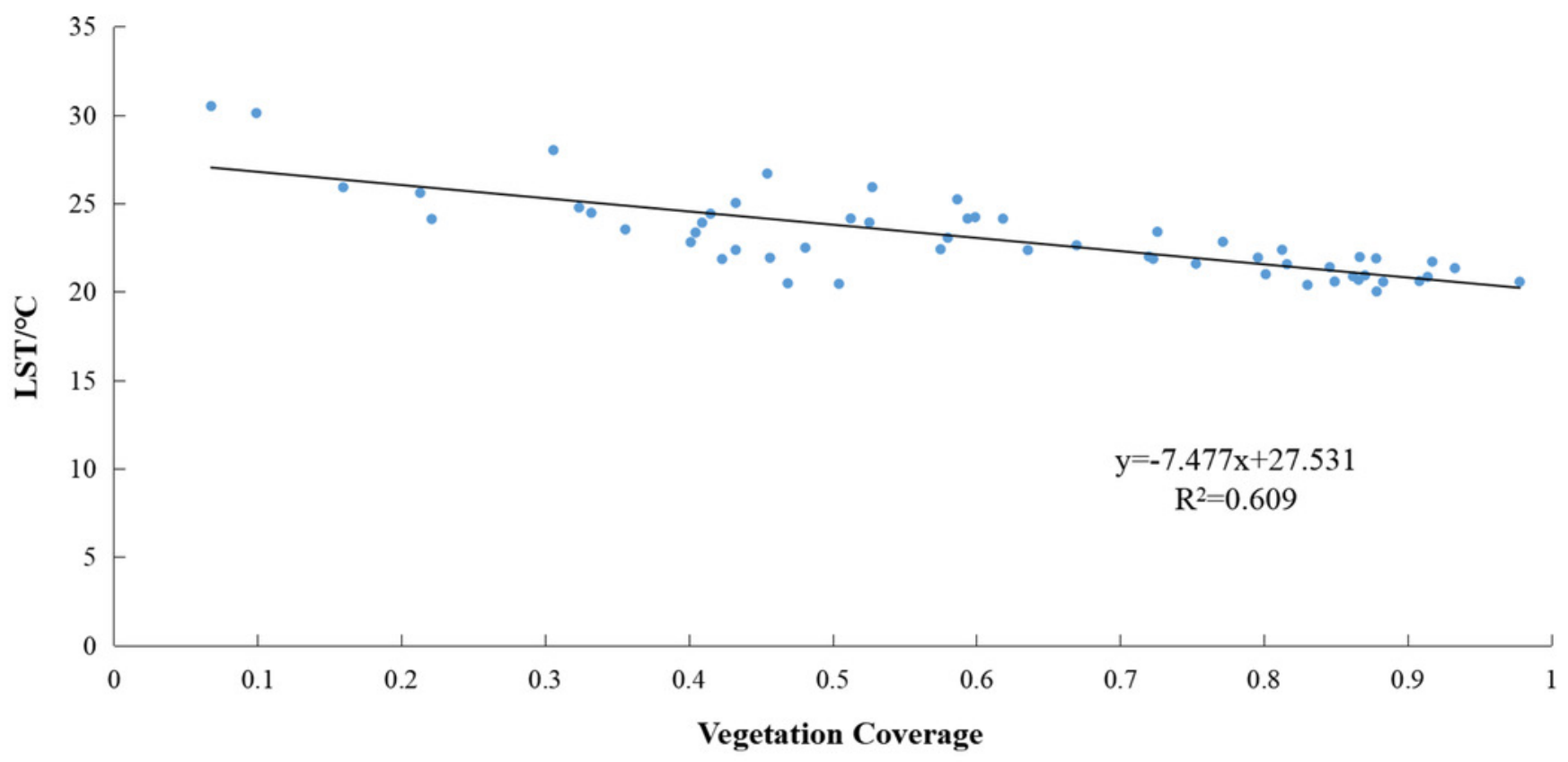


Figure 8

Figure 8 Correlation between patch area and average patch temperature of mining lands

LST, land surface temperature

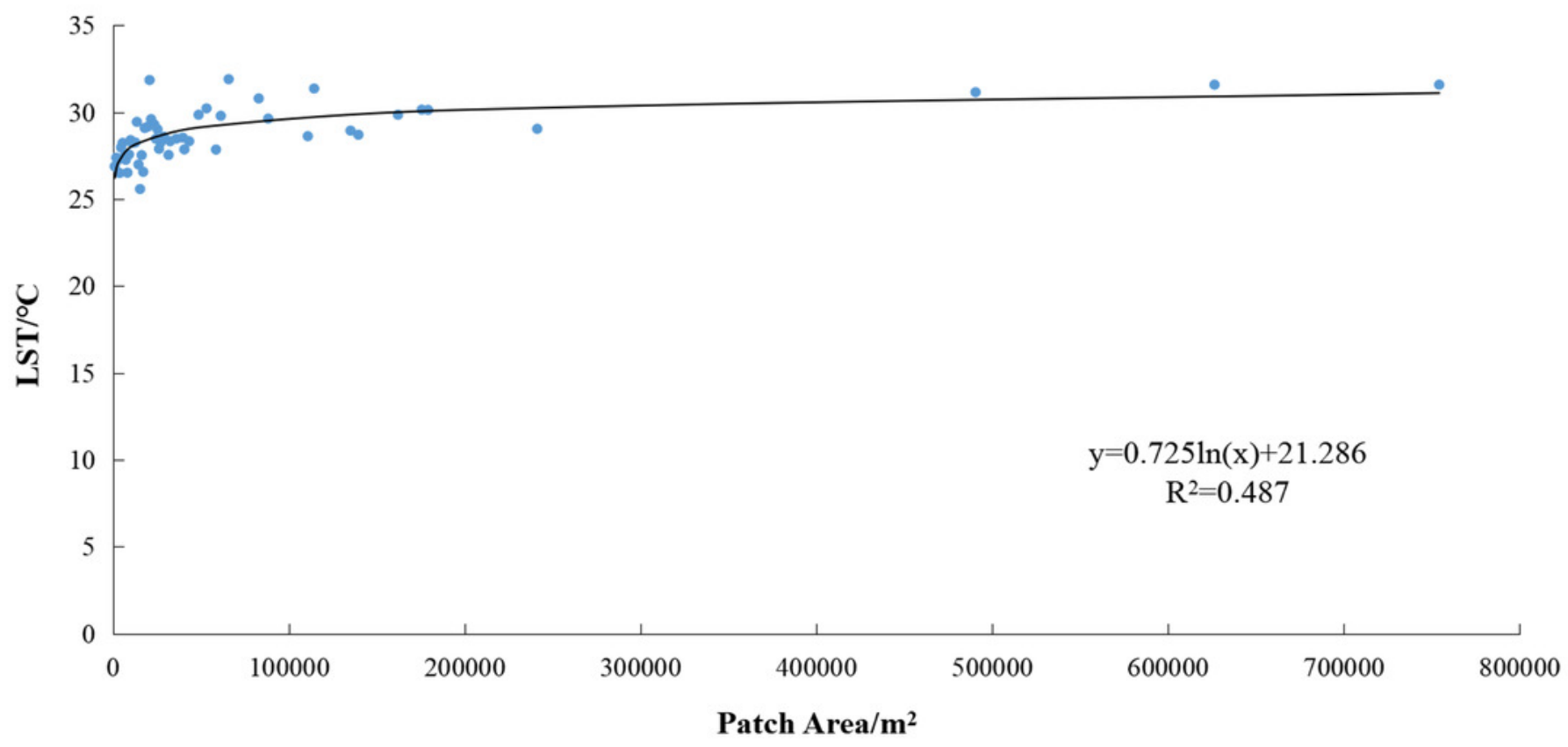


Figure 9

Figure 9 Correlation between patch area and maximum patch temperature of mining lands

LST, land surface temperature

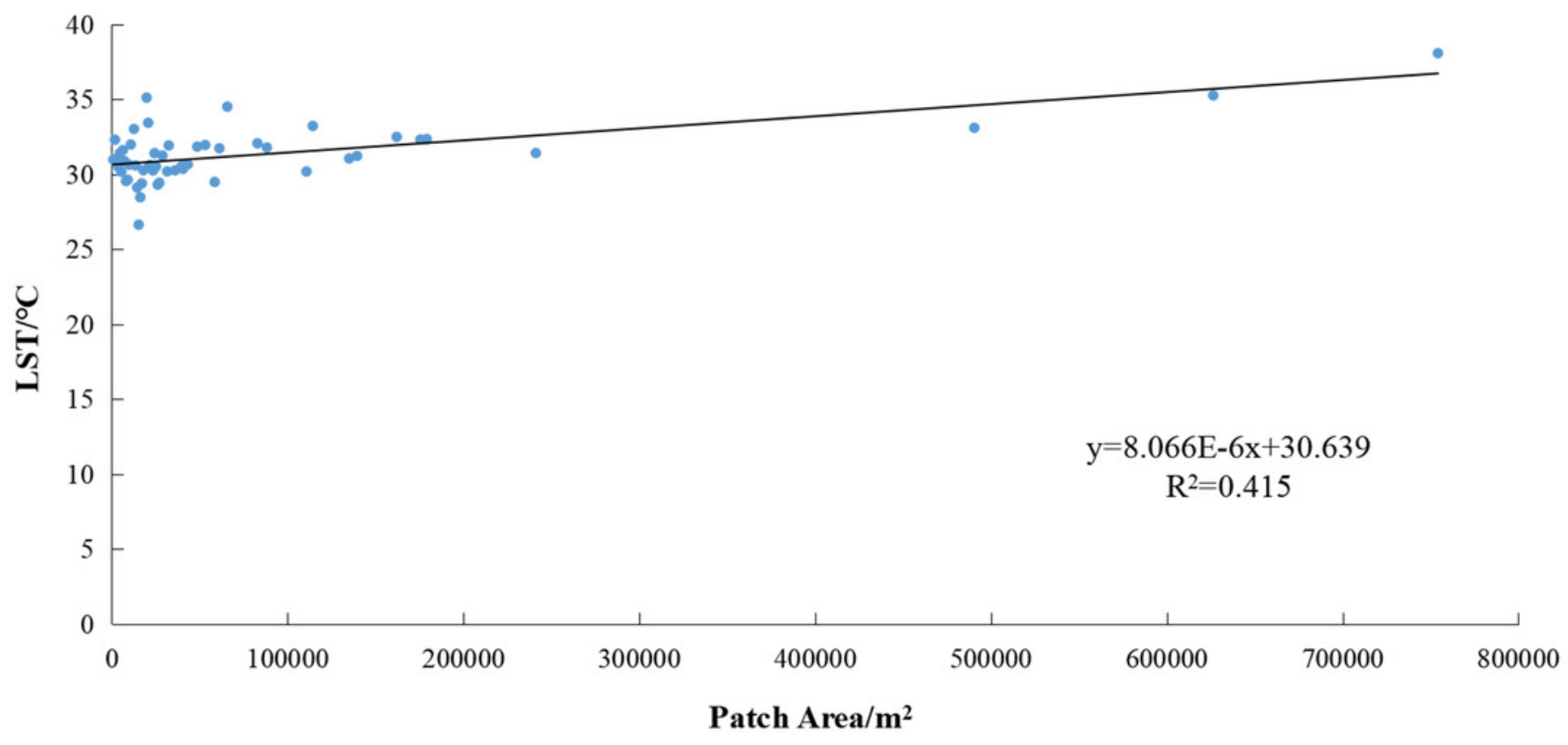


Figure 10

Figure 10 Schematic diagram of buffer zone in mining land patch

The legend has been noted in the figure.

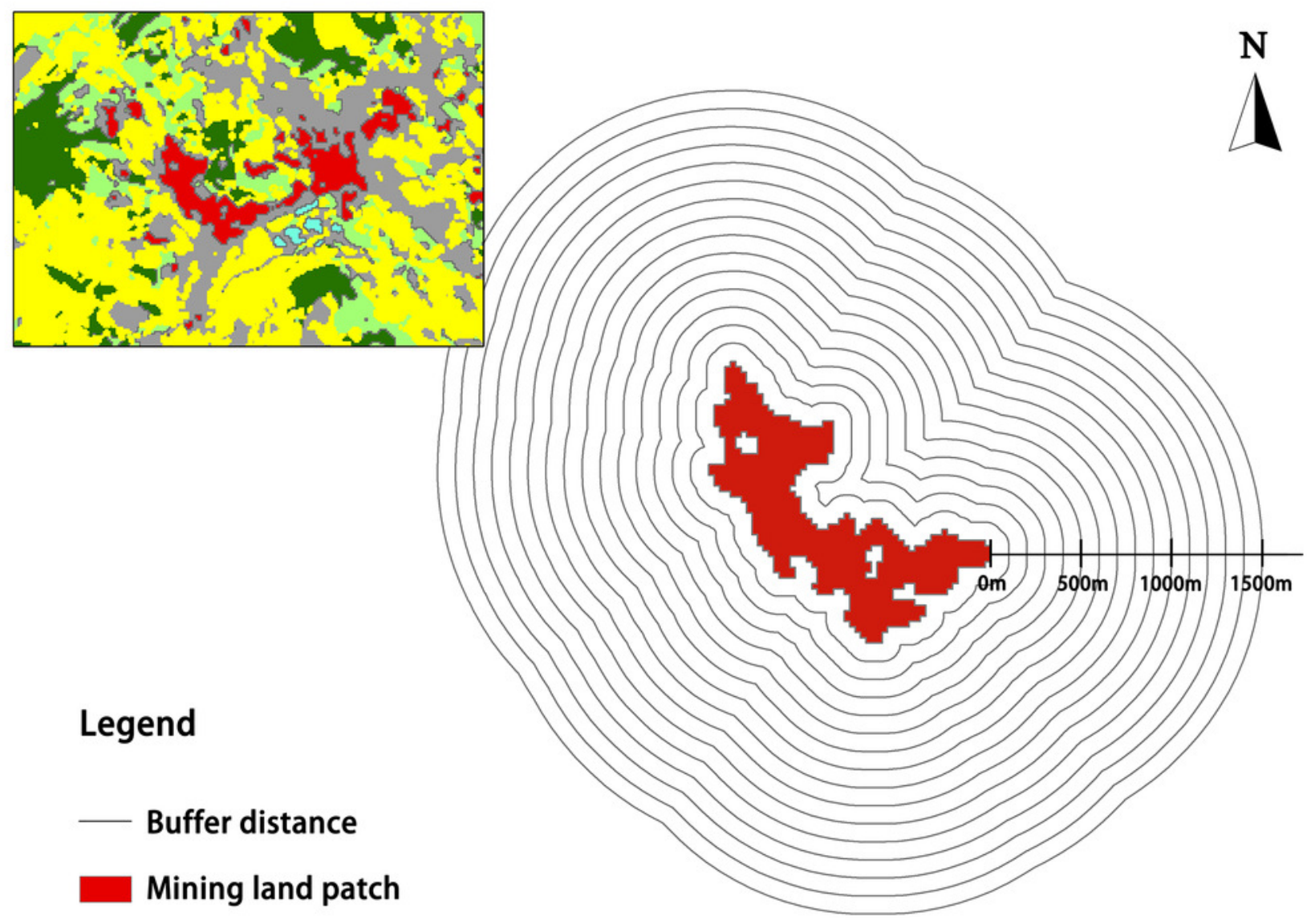


Figure 11

Figure 11 Variation of land surface temperature (LST) with buffer zone of mining lands

The double line on the coordinate axis represents the omitted part of the value, so the $Y$-axis can more clearly re]ect the trend of the four sets of data in the gure.

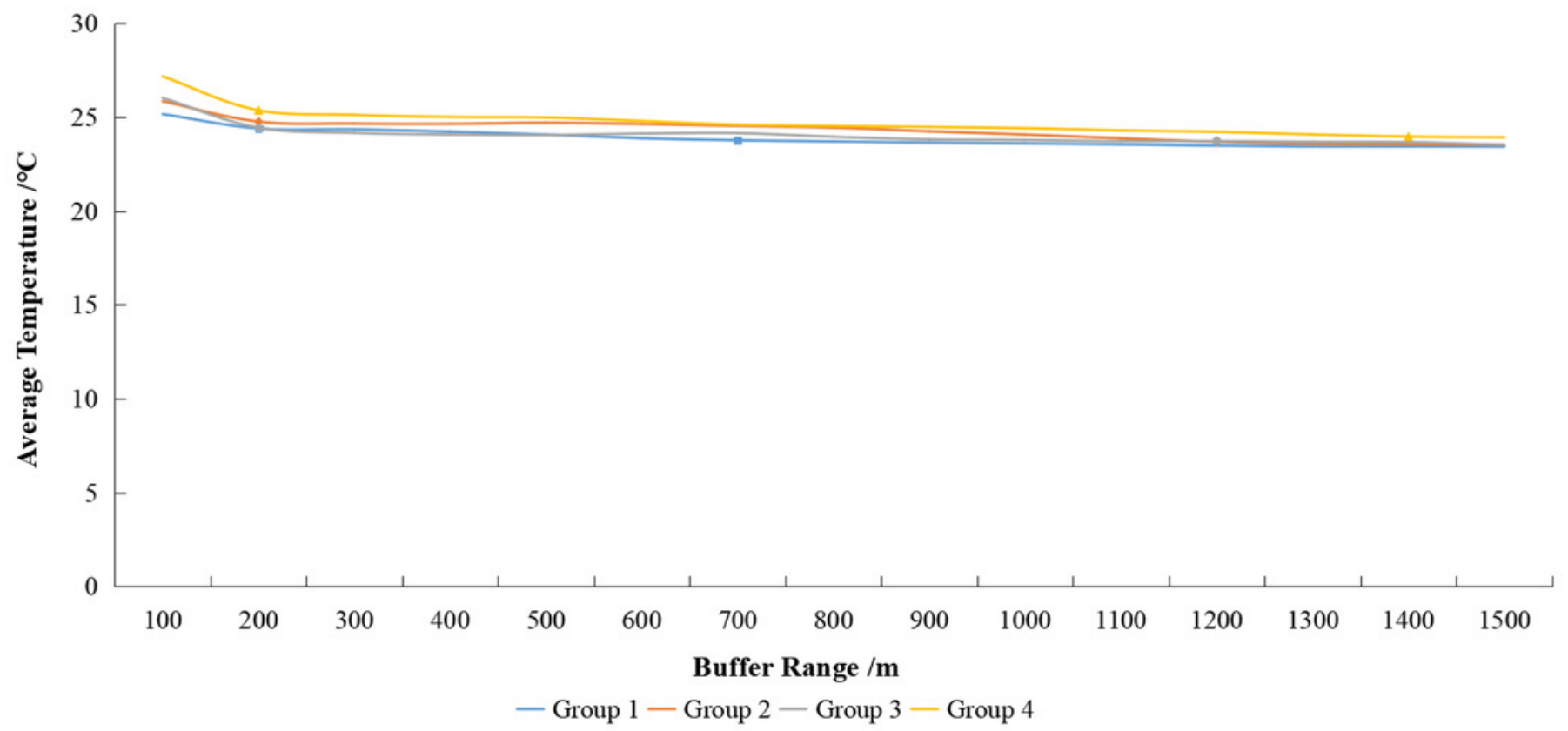

